Atmos. Chem. Phys., 19, 12709-12730, 2019

https://doi.org/10.5194/acp-19-12709-2019

(C) Author(s) 2019. This work is distributed under

the Creative Commons Attribution 4.0 License.

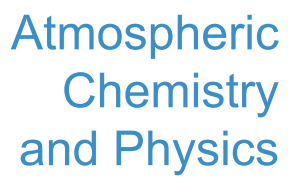

(c) (P)

\title{
Trans-Pacific transport and evolution of aerosols: spatiotemporal characteristics and source contributions
}

\author{
Zhiyuan $\mathrm{Hu}^{1}$, Jianping Huang ${ }^{1}$, Chun $\mathrm{Zhao}^{2}$, Yuanyuan $\mathrm{Ma}^{3}$, Qinjian $\mathrm{Jin}^{4}$, Yun Qian ${ }^{5}$, L. Ruby Leung ${ }^{5}$, \\ Jianrong $\mathrm{Bi}^{1}$, and Jianmin $\mathrm{Ma}^{1}$ \\ ${ }^{1}$ Key Laboratory for Semi-Arid Climate Change of the Ministry of Education, College of Atmospheric Sciences, \\ Lanzhou University, Lanzhou, China \\ ${ }^{2}$ School of Earth and Space Sciences, University of Science and Technology of China, Hefei, Anhui, China \\ ${ }^{3}$ Key Laboratory of Land-surface Process and Climate Change in Cold and Arid Regions, Northwest Institute of \\ Eco-environment and Resources, Chinese Academy of Science, Lanzhou, China \\ ${ }^{4}$ Department of Geography and Atmospheric Science, University of Kansas, Lawrence, KS, USA \\ ${ }^{5}$ Atmospheric Sciences and Global Change Division, Pacific Northwest National Laboratory, Richland, WA, USA
}

Correspondence: Jianping Huang (hjp@lzu.edu.cn)

Received: 3 March 2019 - Discussion started: 20 May 2019

Revised: 28 July 2019 - Accepted: 22 August 2019 - Published: 10 October 2019

\begin{abstract}
Aerosols in the middle and upper troposphere have a long enough lifetime for trans-Pacific transport from East Asia to North America to influence air quality on the west coast of the United States (US). Here, we conduct quasi-global simulations $\left(180^{\circ} \mathrm{W}-180^{\circ} \mathrm{E}\right.$ and $\left.70^{\circ} \mathrm{S}-75^{\circ} \mathrm{N}\right)$ from 2010 to 2014 using an updated version of WRF-Chem (Weather Research and Forecasting model fully coupled with chemistry) to analyze the spatiotemporal characteristics and source contributions of trans-Pacific aerosol transport. We find that trans-Pacific total aerosols have a maximum mass concentration (about $15 \mu \mathrm{g} \mathrm{m}^{-3}$ ) in the boreal spring with a peak between 3 and $4 \mathrm{~km}$ above the surface around $40^{\circ} \mathrm{N}$. Sea salt and dust dominate the total aerosol mass concentration below $1 \mathrm{~km}$ and above $4 \mathrm{~km}$, respectively. About $80.8 \mathrm{Tg}$ of total aerosols ( $48.7 \mathrm{Tg}$ of dust) are exported annually from East Asia, of which $26.7 \mathrm{Tg}$ of aerosols (13.4 Tg of dust) reach the west coast of the US. Dust contributions from four desert regions in the Northern Hemisphere are analyzed using a tracer-tagging technique. About 4.9, 3.9, and 4.5 $\mathrm{Tg} \mathrm{year}^{-1}$ of dust aerosol emitted from north Africa, the Middle East and central Asia, and East Asia, respectively, can be transported to the west coast of the US. The trans-Pacific aerosols dominate the column-integrated aerosol mass $(\sim$ $65.5 \%)$ and number concentration $(\sim 80 \%)$ over western North America. Radiation budget analysis shows that the inflow aerosols could contribute about $86.4 \%\left(-2.91 \mathrm{~W} \mathrm{~m}^{-2}\right)$
\end{abstract}

at the surface, $85.5 \%\left(+1.36 \mathrm{~W} \mathrm{~m}^{-2}\right)$ in the atmosphere, and $87.1 \%\left(-1.55 \mathrm{~W} \mathrm{~m}^{-2}\right)$ at the top of atmosphere to total aerosol radiative effect over western North America. However, near the surface in central and eastern North America, aerosols are mainly derived from local emissions, and the radiative effect of imported aerosols decreases rapidly. This study motivates further investigations of the potential impacts of trans-Pacific aerosols from East Asia on regional air quality and the hydrological cycle in North America.

\section{Introduction}

Atmospheric aerosols, the liquid or solid particulate matter in the atmosphere, are known to be a crucial forcing agent of weather and climate at regional and global scales (Lau et al., 2008; Jimenez et al., 2009; Bond et al., 2013; Huang et al., 2014; Zhao et al., 2011, 2014). Aerosols can change the Earth's energy budget directly by absorbing and scattering solar radiation (Balkanski et al., 2007; Zhao et al., 2010; Jin et al., 2014, 2015; Bi et al., 2017) and indirectly by acting as cloud condensation nuclei $(\mathrm{CCN})$ or ice nuclei (IN) and influence the properties of the cloud (Huang et al., 2006; Creamean et al., 2013; Jin et al., 2016, 2018; Li et al., 2018). When emitted from north Africa, Europe, and East Asia, aerosols could be lifted into the middle and upper tro- 
posphere and subsequently transported by the strong westerlies over the North Pacific basin to North America (Yienger et al., 2000; Holzer et al., 2003, 2005; Liang et al., 2004; Wuebbles et al., 2007; Hu et al., 2016). The trans-Pacific aerosols can affect atmospheric composition (Chin et al., 2007; Yu et al., 2008), stratospheric ozone depletion (Solomon, 1999), surface air quality (VanCuren, 2003; Heald et al., 2006; Chin et al., 2007; Yu et al., 2012; Tao et al., 2016), regional visibility (Watson, 2002), human health (Pope, 2000; Pope et al., 2002; Schwartz, 1994), regional climate (Eguchi et al., 2009; Huang et al., 2009, 2011; Yu et al., 2012; Fan et al., 2014, 2015), and ecological integrity (Bytnerowicz et al., 1996; Schindler, 1988, 1999) in downwind regions, such as the United States (US).

Trans-Pacific aerosols are complex mixtures of natural and anthropogenic aerosols and may potentially impact the western US in many ways (Jaffe et al., 1999; Jacob et al., 2003; Huebert et al., 2003; Parrish et al., 2004; Chin et al., 2007; Fairlie et al., 2007, 2009; Fischer et al., 2009; Singh et al., 2009; Yu et al., 2008, 2012; Hu et al., 2016). Therefore, a number of observation campaigns (e.g., Jacob et al., 2003; Eguchi et al., 2009; Huang et al., 2008; Uno et al., 2011; Yu et al., 2008, 2012) and modeling projects (e.g., Park et al., 2005; Heald et al., 2006; Chin et al., 2007; Hadley et al., 2007; Alizadeh-Choobari et al., 2014; Hu et al., 2016) were undertaken to understand the characteristics and impacts of trans-Pacific aerosols. Previous studies found that aerosols could traverse the Pacific Ocean in about 7-10d (Eguchi et al., 2009) with the largest efficiency in spring (Takemura et al., 2002; Huang et al., 2008; Yu et al., 2012; Eguchi et al., 2009; Uno et al., 2009, 2011). As a major composition of aerosols, mineral dust plays an important role during the trans-Pacific transport. Eguchi et al. (2009) revealed that dust from the Gobi and Taklimakan deserts contributed significantly to the trans-Pacific dust amount, with the Taklimakan dust transported at higher altitudes than Gobi dust. At the surface, trans-Pacific dust increases the fine particle concentration by $5 \%-24 \%$ over the western US on an annual mean, which is about 3 to 4 times more than the transport of anthropogenic pollution to the US on annual average (Chin et al., 2007). Yu et al. (2012) used MODISCALIOP (Moderate-resolution Imaging Spectroradiometer and the Cloud-Aerosol Lidar with Orthogonal Polarization) to estimate the trans-Pacific dust fluxes and shown that about $56 \mathrm{Tg}$ of East Asian dust could reach the western US every year. Anthropogenic aerosols also have an impact comparable to dust during trans-Pacific transport (Takemura et al., 2002; Hadley et al., 2007). It has also been found that transPacific pollutants could increase aerosol concentrations by about $0.2 \mu \mathrm{g} \mathrm{m}^{-3}$ (Chin et al., 2007) over the western US, adding about $0.16 \mu \mathrm{g} \mathrm{m}^{-3}$ of sulfate over the northwestern US (Heald et al., 2006) and increasing black carbon (BC) amount by more than $70 \%$ of locally emitted BC in North America (Hadley et al., 2007).
Trans-Pacific aerosols have significant impact on the climate system and surface air quality through absorbing and scattering of terrestrial and solar radiation (Yu et al., 2012), and modifying cloud and precipitation processes (Ault et al., 2013; Creamean et al., 2013) over the western US. For example, the imported aerosols reduce cloud-free net solar radiation by $-1.7 \mathrm{~W} \mathrm{~m}^{-2}$ at the top of atmosphere (TOA) and $-3.0 \mathrm{~W} \mathrm{~m}^{-2}$ at the surface (SFC) (Yu et al., 2012). The imported pollutants account for $31 \%$ to $59 \%$ of the direct radiative forcing induced by imported dust, because they are more effective in absorbing and scattering solar radiation (Yu et al., 2012). Ault et al. (2011) showed that trans-Pacific dust could increase precipitation by serving as effective ice nuclei and modifying the high-altitude precipitating orographic clouds during the CalWater field campaign. Creamean et al. (2013) demonstrated that the trans-Pacific transported biological aerosols from Saharan and Asian deserts also played an important role in orographic precipitation processes as ice nuclei in the western US. Further, the trans-Pacific transport aerosols can change the stability of the atmospheric boundary layer by absorbing solar radiation (Ramanathan et al., 2008) and accelerate snowmelt and influence the regional climate and hydrological cycle through deposition on snowpack (Painter et al., 2010; Qian et al., 2009, 2015) in western US mountains.

Previous studies have provided a growing sense of the impact of trans-Pacific transport aerosols over the west coast of the US (Jaffe et al., 1999; Jacob et al., 2003; Chin et al., 2007; Yu et al., 2002, 2008, 2012). Most cases reported that the composition and spatial distribution of aerosols were significantly determined by aerosol sizes and number concentration, which could affect cloud formation and distribution (e.g., droplet size, water phase). Serving as effective cloud condensation nuclei, aerosols can potentially enhance or weaken precipitation over the western US (Rosenfeld et al., 2001; Fan et al., 2004; Kelly et al., 2007; Koehler et al., 2007; Eguchi et al., 2009; Creamean et al., 2013). Changing aerosol particle sizes can change the radiative budget through absorbing and scattering solar radiation (Liao and Seinfeld, 2005; Kim et al., 2004), and increasing aerosol number concentration can affect surface air quality (Hu et al., 2016). However, the detailed composition and spatiotemporal characteristics of trans-Pacific aerosols over the west coast of the US, which are critical for investigating aerosol impact, are not well understood. Also, aerosol sizes and number concentrations are not well studied because few analyses are performed on the individual aerosol composition (e.g., dust or sulfate) or the total aerosol quantities. Aerosol aging after long-range transport can change the aerosol compositions and distribution, and increase the uncertainty in estimating aerosol radiative forcing (RF) by more than $100 \%$ or even $200 \%$, which is more significant on a regional scale than on a global scale (Kulmala et al., 2009). More importantly, we quantify the various source contributions in a regional climate model, which has better capabilities of simu- 
lating the large geographical variability and aerosol-cloudprecipitation interaction (Zhao et al., 2013a; Hu et al., 2016). Given the significant amount of dust aerosols from East Asia, the Middle East and central Asia, and north Africa, a better understanding of the source-receptor relationship of dust and the dust source contributions from various desert regions in the Northern Hemisphere to the aerosol abundance on the west coast of the US are warranted.

In this study, we use an updated version of Weather Research and Forecasting (WRF) model with chemistry (WRFChem; Grell et al., 2005) developed at the University of Science and Technology of China (USTC) for quasi-global simulation as described by $\mathrm{Hu}$ et al. (2016, 2019). The quasiglobal simulation of trans-Pacific transport of aerosols with the USTC version of WRF-Chem has been evaluated by $\mathrm{Hu}$ et al. (2016). In this paper, we analyze the experiments with a focus on (1) the characteristics of trans-Pacific aerosols including the spatiotemporal distributions of their chemical compositions; (2) the relative contributions to aerosols from the local emissions in the western US and the long-range transport from East Asia; (3) the contributions from major deserts (i.e., North America, East Asia, north Africa, and elsewhere in the world - mainly for the Middle East and central Asia) to the dust loading over the western US. Section 2 describes the methodology. Section 3 presents the results of the spatiotemporal characteristics of trans-Pacific aerosols and their impacts on aerosol properties over the western US. The conclusions and discussion are provided in Sect. 4.

\section{Methodology}

\subsection{WRF-Chem}

The version of WRF-Chem from USTC is used to conduct quasi-global simulations in this study. The Model for Simulation Aerosol Interactions and Chemistry (MOSAIC) aerosol scheme (Zaveri et al., 2008) is configured in our simulations, which have been coupled with the CBM-Z (i.e., Carbon Bond version Z) photochemical mechanism (Zaveri and Peters, 1999). MOSAIC uses a bin approach with eight discrete size bins to represent aerosol size distributions (Fast et al., 2006). There are eight kinds of aerosol compositions simulated by the model, including the mineral dust, sulfate $\left(\mathrm{SO}_{4}\right)$, nitrate $\left(\mathrm{NO}_{3}\right)$, ammonium $\left(\mathrm{NH}_{4}\right)$, organic matter $(\mathrm{OM})$, black carbon (BC), other inorganic matter (OIN), and sea salt. The physical and chemical processes of aerosols are also included in MOSAIC aerosol scheme. The approach of aerosol dry deposition is followed (Binkowski and Shankar, 1995). Wet removal of aerosols is simulated by the approach of Easter et al. (2004) and Chapman et al. (2009). Moreover, aerosol optical properties (e.g., asymmetry factor for scattering, extinction, single scattering albedo (SSA)) of each model grid box are computed by a function of wavelength. Compared with global models, the USTC version of WRF-Chem used in this study (1) provides a relatively more accurate eight-bin approach to simulate the aerosol mass balance and radiative forcing, which can well simulate particle size distribution and thus aerosol lifetime during long-range transport (Zhao et al., 2013b); (2) includes complex aerosol processes and interactions between aerosol and radiation, clouds, and snow albedo, which can well resolve aerosol-cloud-precipitation interaction (Zhao et al., 2011, 2012, 2014; Hu et al., 2016); and (3) diagnoses radiative forcing of aerosol composition (Zhao et al., 2013a), which is not included in most global models that treat aerosols as internal mixing.

\subsection{Numerical experiments}

The simulations are performed at $1^{\circ}$ horizontal resolution with $360 \times 145$ grid cells $\left(180^{\circ} \mathrm{W}-180^{\circ} \mathrm{E}, 67.5^{\circ} \mathrm{S}-77.5^{\circ} \mathrm{N}\right)$ for the period of 2010-2014, and they are configured with 35 vertical layers from the surface up to $50 \mathrm{hPa}$. The lateral meridional boundary and meteorological initial conditions are derived from the National Centers for Environmental Prediction Final Analysis (NCEP/FNL) data at $1^{\circ}$ horizontal resolution and $6 \mathrm{~h}$ temporal intervals. Dust emission follows Ginoux et al. (2001), which is based on the GOCART (Goddard Chemistry Aerosol Radiation and Transport) dust emission scheme, and the sea salt emission is calculated as Zhao et al. (2013a) based on sea surface temperature (Jaeglé et al., 2011) and the correction of particles with radius less than $0.2 \mu \mathrm{m}$ (Gong, 2003). Anthropogenic emissions are obtained from the Hemispheric Transport of Air Pollution version 2 (HTAPv2) with monthly temporal resolution and the $0.1^{\circ} \times 0.1^{\circ}$ horizontal resolution for each year of 2010-2014 (Janssens-Maenhout et al., 2015). Biomass burning emissions are obtained from the Fire INventory from NCAR (FINN) at $1 \mathrm{~km} \times 1 \mathrm{~km}$ horizontal resolution and 1-hourly temporal resolution (Wiedinmyer et al., 2011). Also, the Morrison two-moment microphysics scheme, RRTMG (the Rapid Radiative Transfer Model) longwave and shortwave radiation schemes, CLMv4.0 (Community Land Model) land surface scheme, and the MYJ (Mellor-Yamada-Janjic) planetary boundary layer scheme are used in this study.

To understand the impact of aerosol trans-Pacific transport on local aerosol properties over the western US, this study analyzes two sets of simulations. The standard simulation includes all natural and anthropogenic emissions across the world, which has been described in detail by Hu et al. (2016). The sensitivity simulation excludes all the emissions from North America $\left(10-70^{\circ} \mathrm{N}\right.$ and $\left.170-60^{\circ} \mathrm{W}\right)$. The difference between the two simulations represents the impact of local emissions over North America. In addition, because the trans-Pacific transported dust has an important impact on air quality and weather over the western US (e.g., Fischer et al., 2009; Creamean et al., 2013), this study applies a tracertagging method in the WRF-Chem simulations to quantify the dust contributions during the trans-Pacific transport. This method tags and explicitly tracks dust particles emitted from 
the independent regions of major deserts within a single simulation through using additional model variables. Four dust source regions are selected in the model, i.e., North America (NAM, $15-50^{\circ} \mathrm{N}$ and $80-140^{\circ} \mathrm{W}$ ), East Asia (EAS, 25- $0^{\circ} \mathrm{N}$ and $75-150^{\circ} \mathrm{E}$ ), north Africa (NAF, $0-40^{\circ} \mathrm{N}$ and $20^{\circ} \mathrm{W}-$ $35^{\circ} \mathrm{E}$ ), and the elsewhere in the world (EIW). It is noted that the advective and physical tendencies of tagged dust variables are simulated in the same way as dust aerosols.

\subsection{Calculating the mass flux of aerosol component}

Firstly, the aerosol mass concentration $M_{\mathrm{p}}\left(\mu \mathrm{g} \mathrm{m}^{-3}\right)$, eastwest wind component $U\left(\mathrm{~m} \mathrm{~s}^{-1}\right)$, and a segment with a length of $L(\mathrm{~m})$ that has a width of $10^{\circ}$ in longitude are used to calculate the aerosol mass flux $\left(\mu \mathrm{g} \mathrm{m}^{-1} \mathrm{~s}^{-1}\right)$ at each model layer. Then, the mass flux multiplies the vertical height of each layer and is aggregated to columnar fluxes. Finally, the calculated 3-hourly fluxes are aggregated into a year. The detailed methodology of Yu et al. (2008) is followed:

$F_{\mathrm{p}}=\sum_{l=1}^{35} M_{\mathrm{p}}(l) U(l) \times L \times H$,

where the $F_{\mathrm{p}}$ is the columnar mass fluxes for aerosols $\left(\mu \mathrm{g} \mathrm{s}^{-1}\right)$, the $M_{\mathrm{p}}$ is aerosol mass concentration $\left(\mu \mathrm{g} \mathrm{m}^{-3}\right), U$ is east-west wind component $\left(\mathrm{m} \mathrm{s}^{-1}\right), L$ is the length with a width of $10^{\circ}$ in longitude $(\mathrm{m}), H$ is the vertical height of each layer (m), and $l$ is the model layer.

\section{Results and discussion}

\subsection{Characteristics of trans-Pacific aerosols}

\subsubsection{Spatial distribution of total mass}

Firstly, $\mathrm{Hu}$ et al. (2016) evaluated the simulations with various satellite retrievals and surface measurements, including AOD (aerosol optical depth) from MODIS, MISR (Multi-angle Imaging SpectroRadiometer), OMI (Ozone Monitoring Instrument), and AERONET (AErosol RObotic NETwork), aerosol extinction coefficients from the CloudAerosol Lidar and Infrared Pathfinder Satellite Observation (CALIPSO), and the surface mass concentration from IMPROVE (Interagency Monitoring of PROtected Visual Environments). The difference of annual mean AOD between simulations and MODIS (MISR) retrievals was about -0.01 $(+0.01), 0(0)$, and $-0.01(-0.01)$ over the western, central, and the eastern Pacific. Across the Pacific, the spatial correlation coefficients of AOD between simulations and satellite retrievals (e.g., MODIS and MISR) were in the range of $0.63-0.88$ for the four seasons. Also, compared with AERONET measurements, about $90 \%$ of simulated AOD was within a factor of 2 , and their monthly correlation coefficients were about $0.64-0.76$. Additionally, the simulations could well capture the magnitude of aerosol surface mass concentrations over the western US with correlation coefficients of $0.75-0.83$. Overall, these results showed that the simulations well captured the spatial distribution and vertical profile characteristics of trans-Pacific transport aerosols. Figure 1 shows the spatial distribution of seasonal mean aerosol mass concentrations across the Pacific Ocean from the simulation averaged for the period of 2010-2014. The trans-Pacific transport of aerosol mass concentrations has similar spatial distribution and seasonal variability to that of AOD discussed by previous studies (e.g., Chin et al., 2007; Yu et al., 2008, 2012; Hu et al., 2016). Aerosol exports from the East Asian continent, a gradual decrease of aerosol concentrations across the Pacific Ocean, and imports of aerosols into North America are clearly seen in all seasons. In the Taklimakan and Gobi deserts (for dust) and India and South Asia (for anthropogenic aerosol), significant amounts of aerosols are produced, and the aerosol mass loadings can reach $320 \mathrm{mg} \mathrm{m}^{-2}$ (Fig. 1). During long-range transport, aerosols with high mass concentrations coincide with the subtropical jet and reach the west coast of the US. The peak trans-Pacific aerosol mass concentrations occur in spring (MAM) due to the strongest midlatitude westerlies and active extratropical cyclones (particularly south of $30^{\circ} \mathrm{N}$ ) (Yu et al., 2012), and more emissions in this season (Yu et al., 2008), while the minimum occurs in summer (JJA) because of the greatest aerosol removal induced by summer monsoon precipitation (Holzer et al., 2005; Yu et al., 2008, 2013). The modeling results indicate that the spatial distribution of aerosols is similar in all seasons. About $25 \%$ of exported aerosols from Asia arrive on the west coast of the US (Fig. 1), which is consistent with the MODIS-CALIOP assessment (Yu et al., 2008). In general, the strong spatial and seasonal variations of aerosol mass concentrations are due to the seasonal variations of emissions of aerosols and their precursors, the midlatitude westerlies, and extratropical cyclones (Yu et al., 2008, 2012; Fast et al., 2014; Hu et al., 2016).

The seasonal variation of the vertical cross section of zonal-mean aerosol mass concentrations averaged for 20102014 shows large latitudinal and vertical gradients in aerosol mass concentrations appearing through all seasons (Fig. 2). In MAM, the maximum aerosol mass concentration occurs below $4 \mathrm{~km}$ with about $15 \mu \mathrm{g} \mathrm{m}^{-3}$ within the $27-44^{\circ} \mathrm{N}$ segment, consistent with previous research results (e.g., Huang et al., 2014; Hu et al., 2016). From 1 to $8 \mathrm{~km}$, aerosol mass concentrations are about $10 \mu \mathrm{g} \mathrm{m}^{-3}$ in the $35-45^{\circ} \mathrm{N}$ segment, which is the largest compared to the other three seasons. In winter (DJF), there are about $4 \mu \mathrm{g} \mathrm{m}^{-3}$ of aerosol mass concentrations below $2-6 \mathrm{~km}$ across 25 to $50^{\circ} \mathrm{N}$. For JJA and SON, the segment of higher concentrations shifts further north to $35-50^{\circ} \mathrm{N}$, potentially related to the northward shift of the easterlies and the reduced strength of the westerlies, along with precipitation removal increasing in the outflow region (Yu et al., 2008). Similar to the horizontal spatial distribution (Fig. 1), the vertical distribution of aerosol mass 

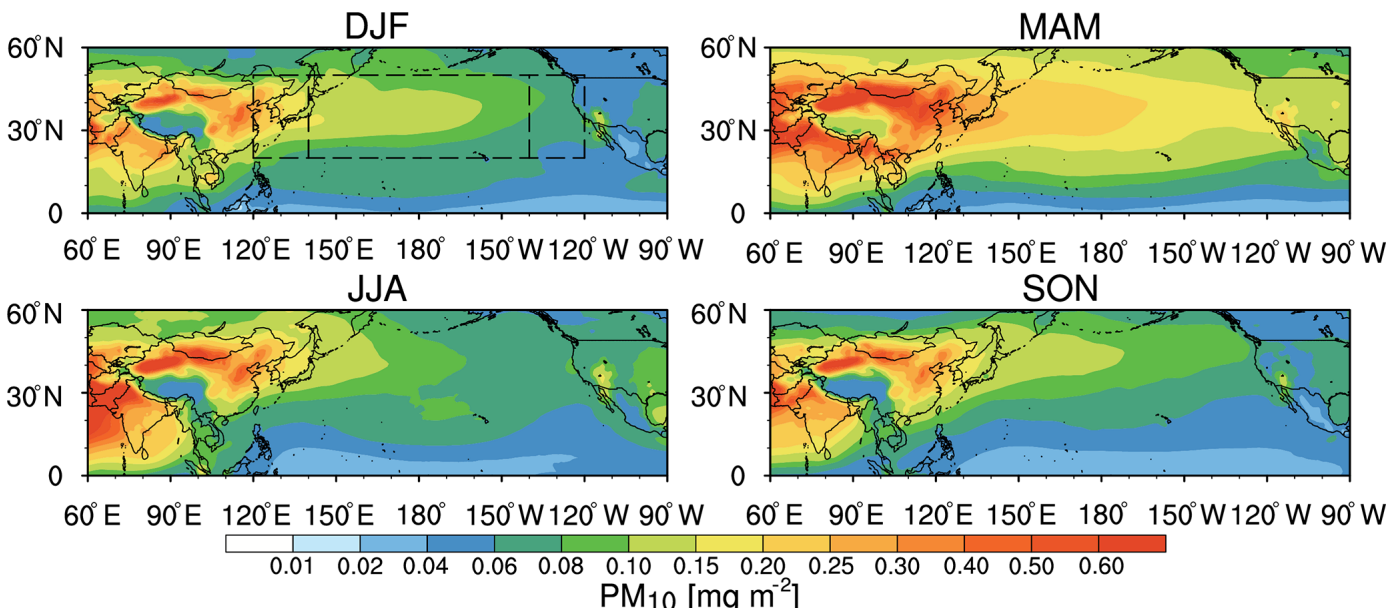

Figure 1. Spatial distribution of seasonal mean aerosol column mass loading from WRF-Chem averaged for 2010-2014. Three regions are denoted by the black boxes: the western Pacific $\left(20-50^{\circ} \mathrm{N}\right.$ and $\left.120-140^{\circ} \mathrm{E}\right)$, the central Pacific $\left(20-50^{\circ} \mathrm{N}\right.$ and $\left.140^{\circ} \mathrm{E}-140^{\circ} \mathrm{W}\right)$, and the eastern Pacific $\left(20-50^{\circ} \mathrm{N}\right.$ and $\left.140-120^{\circ} \mathrm{W}\right)$ for analysis. $\mathrm{PM}_{10}$ is including the mineral dust, sulfate $\left(\mathrm{SO}_{4}\right)$, nitrate $\left(\mathrm{NO}_{3}\right)$, ammonium $\left(\mathrm{NH}_{4}\right)$, organic matter $(\mathrm{OM})$, black carbon $(\mathrm{BC})$, other inorganic matter $(\mathrm{OIN})$, and sea salt.
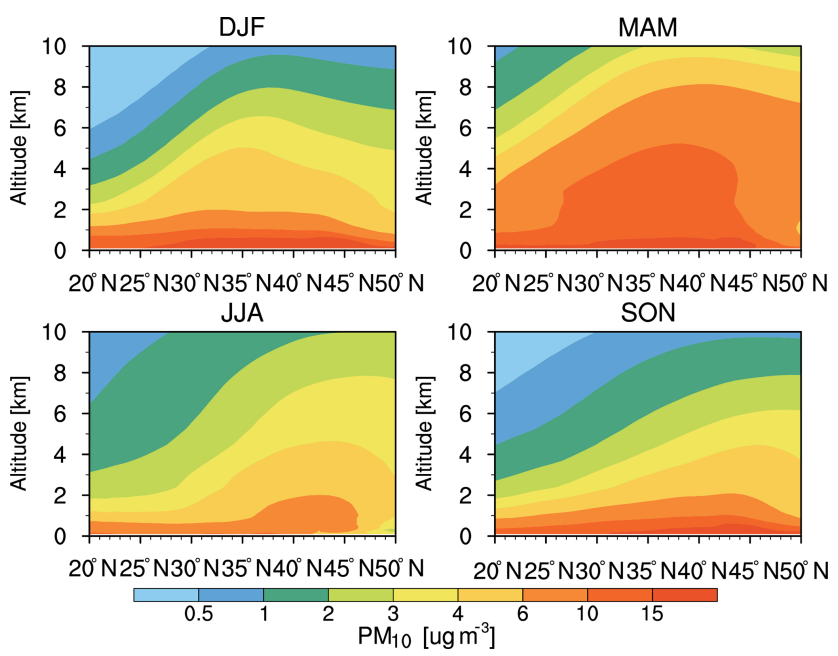

Figure 2. Vertical cross section of zonal-mean aerosol mass concentration averaged from $120^{\circ} \mathrm{E}$ to $120^{\circ} \mathrm{W}$ for each season from the WRF-Chem simulation averaged for 2010-2014.

concentrations is the largest in MAM due to the strong frontal and postfrontal convection and atmospheric boundary layer turbulent mixing that lift more aerosols to the troposphere (Yu et al., 2008). Note that the largest aerosol mass concentrations appear below $1 \mathrm{~km}$ in the seasons that are dominated by sea salt (figure not shown).

\subsubsection{Spatial distribution of aerosol components}

Figure 3 shows the annual mean spatial distribution of column-integrated mass of various aerosol compositions. The amounts of trans-Pacific aerosols are estimated from the sensitivity simulation with all emissions from North America excluded. The results show that the trans-Pacific aerosols can reach the western US and even the central US. Four types of dust tracers emitted from the four regions of NAM, EAS, NAF, and EIW with major deserts (defined in Sect. 2) are also shown. With the dust-tracking method, the dust from multiple sources mixed in the outflow of Asia (Chin et al., 2007) can be isolated. The result shows that dust from EAS, NAF, and EIW is the major contributor to the trans-Pacific dust over the North Pacific. The NAF dust is not only transported across northern Africa into Europe (Park et al., 2005; Lee et al., 2010) but also has been found to mix with EIW dust (mainly from the Middle East and central Asian dust sources) and could be carried eastward to East Asia (Hu et al., 2018) (Fig. 3). Over East Asia, the EAS dust is mainly from local sources (e.g., Taklimakan and Gobi desert), followed by the NAF dust and EIW dust from intercontinental transport (e.g., Sahara and Arabian desert). Among the three major tagged source regions, the EAS dust contributes about $28.3 \%$ $\left(22.34 \mathrm{mg} \mathrm{m}^{-2}\right)$ to the total aerosol mass loading over East Asia. The NAF dust contributes about $11.0 \%\left(8.71 \mathrm{mg} \mathrm{m}^{-2}\right)$, and the EIW dust contributes about $9.0 \%\left(7.11 \mathrm{mg} \mathrm{m}^{-2}\right)$, respectively. Other aerosol compositions (e.g., sulfate, nitrate, ammonium, organic matter, black carbon, other inorganic matter, and sea salt) also have significant contributions to the trans-Pacific transport aerosols, with about $51.6 \%$ contribution over East Asia.

The EAS dust with mass loading of $7.60 \mathrm{mg} \mathrm{m}^{-2}$ decreases rapidly during transport because of dry deposition 

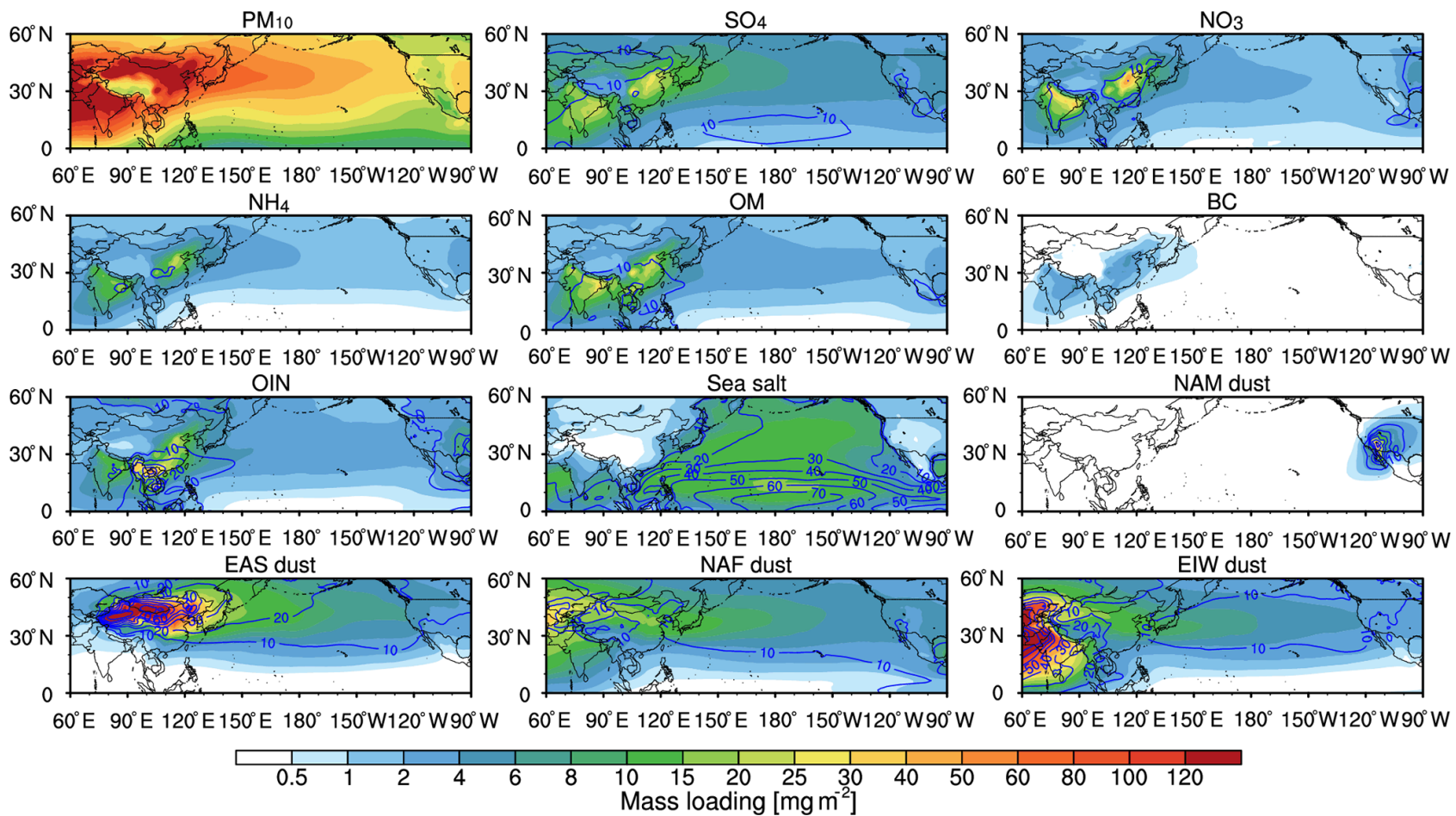

Figure 3. Spatial distribution of aerosol composition column mass loading from WRF-Chem averaged for 2010-2014. The trans-Pacific transport aerosol mass spatial distribution is denoted by $\mathrm{PM}_{10}$ and the dust from North America, East Asia, north Africa, and elsewhere in the world is denoted by NAM dust, EAS dust, NAF dust, and EIW dust. Contour lines (blue solid line) denote the percentage contribution (\%) of the corresponding aerosol composition to total aerosol column mass.

(gravitational sedimentation and turbulent mix-out) near the source region (Zhao et al., 2012; Huang et al., 2014) and wet deposition (precipitation scavenging) (Easter et al., 2004; Chapman et al., 2009) during the long-range transport. For NAF dust and EIW dust, they reside mainly in the upper troposphere, which results in less dry and/or wet deposition, so they contribute about $13.7 \%\left(6.24 \mathrm{mg} \mathrm{m}^{-2}\right)$ and $11.1 \%$ $\left(5.07 \mathrm{mg} \mathrm{m}^{-2}\right)$ to total aerosol mass loading. The mass loading of other aerosol compositions is $26.67 \mathrm{mg} \mathrm{m}^{-2}$, which is about $58.6 \%$ of total aerosol mass concentration.

On the west coast of the US, dust contributes about $41.1 \%$ compared to other aerosol mass loading, followed by sea salt with about $21.7 \%$. For the dust contribution, EAS dust, NAF dust, and EIW dust contribute $14.6 \%\left(4.79 \mathrm{mg} \mathrm{m}^{-2}\right)$, $14.0 \%\left(4.59 \mathrm{mg} \mathrm{m}^{-2}\right)$, and $11.0 \%\left(3.60 \mathrm{mg} \mathrm{m}^{-2}\right)$ to total aerosol mass loading, respectively. However, the mass loading of NAM dust (about $0.48 \mathrm{mg} \mathrm{m}^{-2}$ ) is far lower than the trans-Pacific dust. Also, the other aerosol compositions are $19.24 \mathrm{mg} \mathrm{m}^{-2}$. In general, the trans-Pacific transported dust mass loading is about 1-2 times larger than that of the transported pollution in this region, and the transported dust at the surface is $2-4$ times higher than that of pollution, which has been discussed by Chin et al. (2007).

Figure $4 \mathrm{a}-\mathrm{c}$ illustrate the cross section of zonal aerosol mass concentration vertical distribution from the WRF-
Chem model simulation over three subregions (the western Pacific: $20-50^{\circ} \mathrm{N}$ and $120-140^{\circ} \mathrm{E}$; the central Pacific: 20 $50^{\circ} \mathrm{N}$ and $140^{\circ} \mathrm{E}-140^{\circ} \mathrm{W}$; the eastern Pacific: $20-50^{\circ} \mathrm{N}$ and $140-120^{\circ} \mathrm{W}$ ) (shown as the black boxes in Fig. 1). Aerosol mass concentrations decrease evidently with elevation along the Pacific Ocean with a dramatic reduction from around 15 to $1 \mu \mathrm{g} \mathrm{m}^{-3}$ from the surface to about $10 \mathrm{~km}$. Over the western Pacific, the aerosol mass concentration is the highest below $2 \mathrm{~km}$ in the $30-45^{\circ} \mathrm{N}$ segment, with a peak value of $15 \mu \mathrm{g} \mathrm{m}^{-3}$. The higher aerosol mass concentrations are attributed to outflow of dust and pollution aerosols in this region (e.g., Yu et al., 2012; Huang et al., 2014; Hu et al., 2016). Over the central and eastern Pacific, because of wet/dry deposition (Zhao et al., 2012), the aerosol mass concentrations decrease rapidly compared to those of the western Pacific. Larger aerosol mass concentrations occur below about $1 \mathrm{~km}$ in the central Pacific (about $10 \mu \mathrm{g} \mathrm{m}^{-3}$ ) and about $0.8 \mathrm{~km}$ in the eastern Pacific (about $8 \mu \mathrm{g} \mathrm{m}^{-3}$ ). To characterize the aerosol vertical distribution, we show the profiles of total aerosol mass concentrations and vertical distributions of aerosol composition fractions in Fig. 4d-f. Below $1 \mathrm{~km}$, the sea salt is the dominant aerosol over the Pacific Ocean, and the dust and pollution aerosol outflow from East Asia makes significant contributions over the western Pacific. Above $4 \mathrm{~km}$, dust dominates the aerosol mass concentrations 
(a) Western Pacific

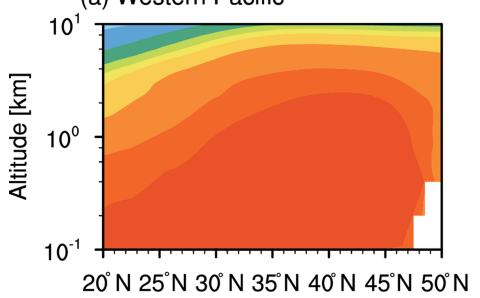

(b) Central Pacific

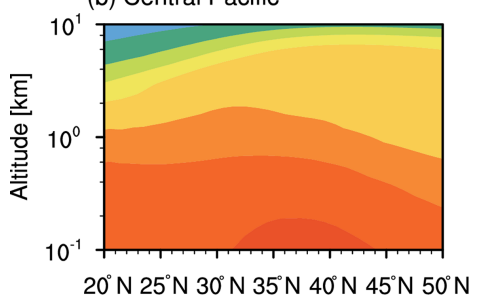

(c) Eastern Pacific

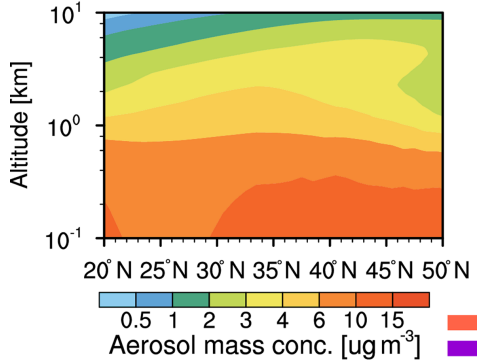

Aerosol mass conc. [ug m ${ }^{-3}$ ]
Aerosol mass conc. [ug m $\mathrm{m}^{-3}$ ] (d) $0 \quad 5 \quad 10 \quad 15 \quad 2025 \quad 30$

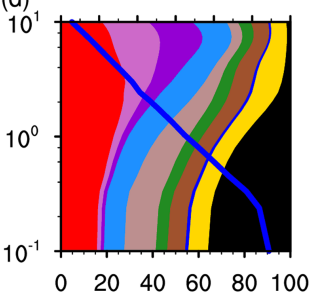

(e) $0 \quad 5 \quad 10 \quad 15 \quad 20 \quad 2530$

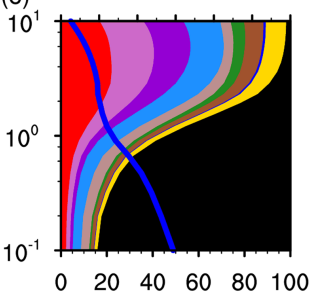

(f) $\quad 0 \quad 5 \quad 10 \quad 15 \quad 20 \quad 25 \quad 30$

$10^{1}$

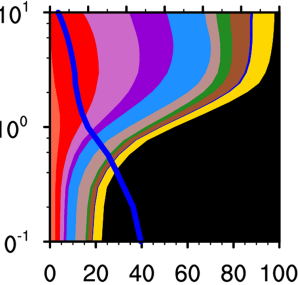
Fraction [\%]
NAM dust EAS dust NAF dust

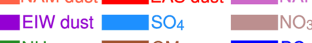

$\mathrm{NH}_{4}$

OIN Sea salt

Figure 4. Vertical cross section of zonal-mean aerosol mass concentration $(\mathbf{a}, \mathbf{b}, \mathbf{c})$ and vertical distributions of mean aerosol mass (solid blue line; upper $x$ axis) and the composition fractions (colored shade contour; lower $x$ axis) (d, e, f) from the WRF-Chem simulation averaged for 2010-2014 over the three regions shown in Fig. 1.

in all three subregions. Significantly, the EAS dust is the dominant dust contributor below $4 \mathrm{~km}$, and the NAF dust and EIW dust are comparable to the EAS dust above $4 \mathrm{~km}$. During the trans-Pacific transport, the NAF dust and EIW dust increase with altitude and contribute aerosol mass concentrations that are close to the EAS dust above $2 \mathrm{~km}$. Overall, the EAS dust is the major dust aerosol over the eastern and central Pacific below $1 \mathrm{~km}$ (excluding sea salt). Above $2 \mathrm{~km}$, dust from all three sources has a similar contribution. Notably, anthropogenic aerosols (i.e., sulfate and nitrite) also make significant contributions over the three subregions, even above $2 \mathrm{~km}$. Over the western Pacific, the anthropogenic aerosols contribute about more than $40 \%$ mass concentrations above $2 \mathrm{~km}$, in which the largest is sulfate, with $15 \%$ contribution, followed by OIN $(12 \%)$ and OM $(8 \%)$. Over the central and eastern Pacific, the anthropogenic aerosol contribution is similar above $2 \mathrm{~km}$, in which the sulfate is about $15 \%$, followed by OIN $(8 \%)$ and OM $(6 \%)$.

\subsubsection{Mass versus number concentrations}

The size of aerosol particles can range from nanometer to micrometer, which is a critical factor influencing clouds, precipitation, and surface air quality (Yu et al., 2008; Zhao et al., 2013b). However, few studies have focused on aerosol number loading during the trans-Pacific transport. Zhao et al. (2013b) demonstrated that the WRF-Chem model configured with eight size bins could appropriately describe the aerosol size distributions and the changes of mass fraction of coarse and fine particles during the long-range transport. Figure 5 shows the fractional contributions of different aerosol compositions to seasonal and annual mean aerosol mass and number over the three subregions. Aerosol mass and number concentrations show significantly different fractions even for the same aerosol species in various regions. They decrease along the Pacific Ocean from west to east, with a peak in MAM. Dust dominates the total aerosol mass concentrations and accounts for more than $50 \%$ in MAM (Fig. 5). Over the western Pacific, the EAS dust is the dominant dust aerosol, but for the central and eastern Pacific, dust from different sources has more comparable contributions. In DJF, the NAF dust and EIW dust mass is greater than that of the EAS dust over the eastern Pacific, but they have similar mass in JJA and SON. Hence, it is shown clearly that the dust outflow from EAS does not originate from the EAS local region alone but also from NAF and EIW (Middle East and central Asia).

Unlike the aerosol mass contributions, the aerosol number contributions are dominated by fine sulfate particles. Over the western Pacific, the contribution of sulfate is more than $45 \%$, with a peak in JJA at $50 \%$. This is attributed to the higher photochemical activity in the warm season (Hu et al., 2016). During the transport over the central and eastern $\mathrm{Pa}$ cific, the contribution of sulfate becomes more than $60 \%$. Relatively, the nitrate decreases rapidly to less than $4 \%$ during the trans-Pacific transport, which is likely due to the fact that nitrate particles are mainly concentrated in the low level over the western Pacific (shown in Fig. 6) and can be removed easily during the transport. The aerosol number concentrations are dominated by fine sulfate particles, followed by fine ammonium and organic matter particles. Compared with fine pollution aerosols, the dust aerosol number contribution is much lower (less than $1 \%$ ) due to the much larger particle size. Furthermore, Chin et al. (2007) found that sulfate from Europe is the main source of the trans-Pacific transport pollution aerosol, and more sulfate particles remain at the higher altitude when they are imported to the eastern $\mathrm{Pa}$ cific. Therefore, only limited sulfate could be removed during the transport, and most of the sulfate particles can reach the eastern Pacific.

Figure 6 shows the vertical distribution of mass and number fractions of various aerosol compositions. Dust mass from three sources dominates the total aerosol mass concentrations above $4 \mathrm{~km}$ (about $60 \%$ ) over the western, central, and eastern Pacific, while, below $4 \mathrm{~km}$, the dust mass contri- 

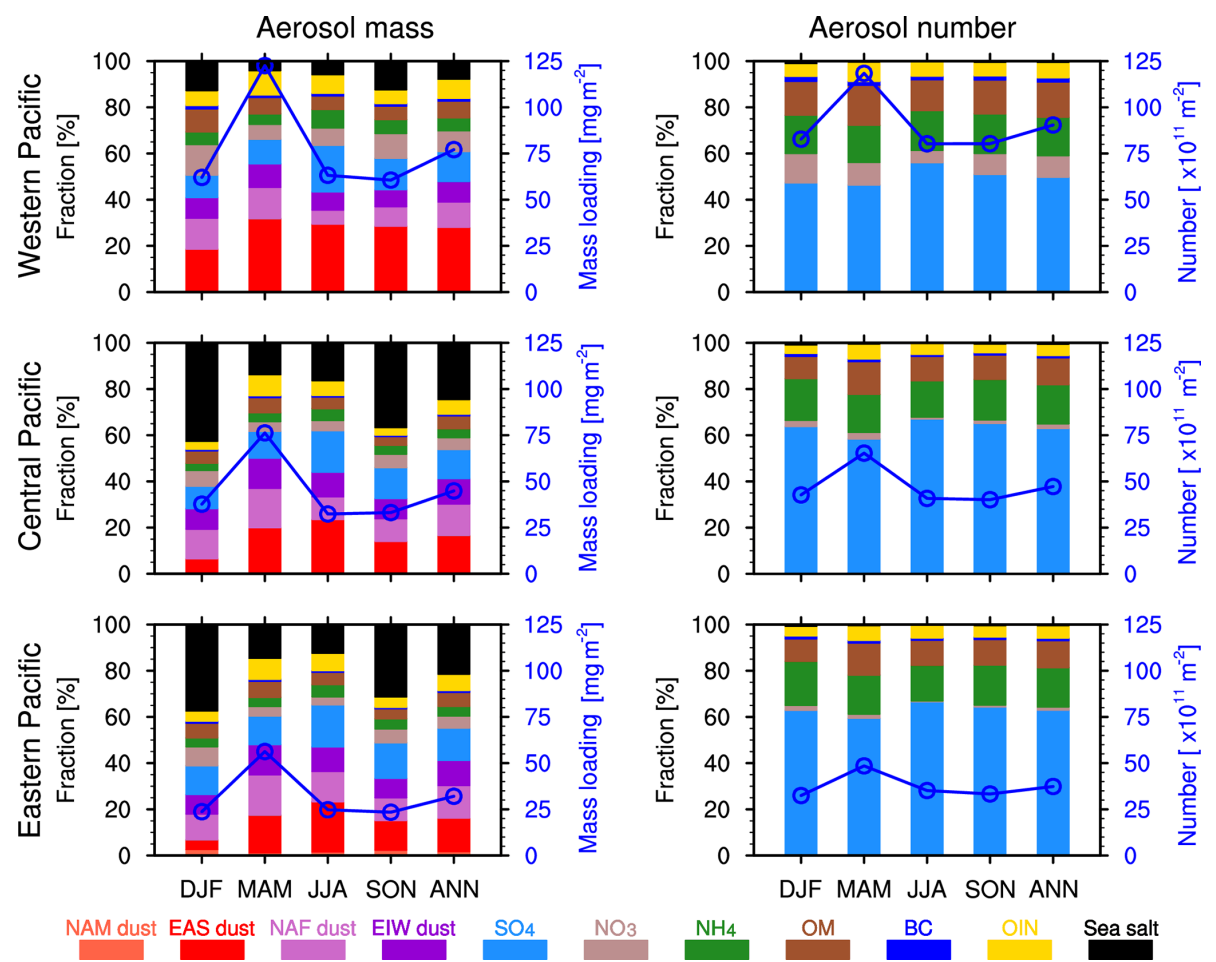

Figure 5. Fractional contributions for seasonal and annual mean aerosol mass and number over the western, central, and eastern Pacific from the WRF-Chem simulation averaged for 2010-2014.

butions are varying with a range of 5\%-58\%. Sea salt is the dominant aerosol species that contributes more than $40 \%$ of mass over the central and eastern Pacific below $2 \mathrm{~km}$. Also, the EAS dust mass is distributed throughout the column with a peak at $2 \mathrm{~km}$, but the NAF dust and EIW dust are distributed mainly above $4 \mathrm{~km}$ over the western Pacific. Over the eastern Pacific, the EAS dust and NAF dust mass is mainly located above $1 \mathrm{~km}$. For particle number, sulfate provides larger contribution in the column atmosphere, and organic matter is similar to sulfate over the western Pacific, which is attributed to biomass burning and the use of coal in Asia (Bian et al., 2007; Yu et al., 2008). During the transport, the aerosol number changes very little because of the minimal wet removal above $400 \mathrm{hPa}$, but there are larger changes because of precipitation removal below $800 \mathrm{hPa}$ (not shown).

To better understand the vertical profiles of aerosol size distribution, the modeled size distributions of aerosol mass and number over the three subregions averaged for 20102014 are shown in Fig. 7. Aerosols of size 2.5-10.0 $\mu \mathrm{m}$ contribute mainly to aerosol mass below $1 \mathrm{~km}$, with a maximum at $5.0 \mu \mathrm{m}$ (about $40 \%$ ). Above $2 \mathrm{~km}$, aerosols of size 1.25-5.0 $\mu \mathrm{m}$ (Bin4-Bin7) become the major size range with more than $35 \%$ contribution. In the range of $0.312-1.25 \mu \mathrm{m}$, the contribution is about $15 \%$. There is a significant aerosol mass distribution in Bin4 $(0.312-0.625 \mu \mathrm{m})$ above the surface to $4 \mathrm{~km}$ over the western Pacific. For aerosol number, the 0.039-0.156 $\mu \mathrm{m}$ (Bin1-Bin3) aerosols are the main con- tributors and dominate the aerosol number during aerosol trans-Pacific transport. The Bin1 fraction increases with altitude over the western Pacific, which indicates clearly the decreasing aerosol size with increasing altitude. However, during the transport pathway, aerosol size changes little over the central and eastern Pacific which are dominated by fine particles $(0.039-0.156 \mu \mathrm{m})$. This analysis suggests that the aerosol mass is dominated by Bin6 and Bin7, but the number is dominated by Bin1.

\subsection{Aerosol fluxes across the North Pacific}

To better understand the source-receptor relationships, aerosol compositional mass flux exported from East Asia and imported to North America is estimated. The mass flux is estimated using zonal wind speed with a width of $10^{\circ}$ in longitude, as illustrated in Fig. 8. We calculate the aerosol mass flux from 20 to $50^{\circ} \mathrm{N}$ centered at $130^{\circ} \mathrm{E}$ to represent the East Asian outflow, at $180^{\circ} \mathrm{E}$ to represent the North Pacific, and at $130^{\circ} \mathrm{W}$ to represent North America inflow, respectively. On an annual basis, $48.7 \mathrm{Tg}_{\text {year }}{ }^{-1}$ of dust and $32.1 \mathrm{Tg}$ year $^{-1}$ of pollution aerosols are exported from East Asia $\left(20-50^{\circ} \mathrm{N}\right)$, and $13.4 \mathrm{Tg}_{\text {year }}{ }^{-1}$ of dust and $10.3 \mathrm{Tg}_{\text {year }}{ }^{-1}$ of pollution are imported to the west coast of the US. The modelestimated pollution aerosol mass flux is greater than the MODIS-estimated mass flux (about $14.0 \mathrm{Tg}$ year $^{-1}$ exported from East Asia; $4.4 \mathrm{Tg}_{\text {year }}{ }^{-1}$ imported into North America) 

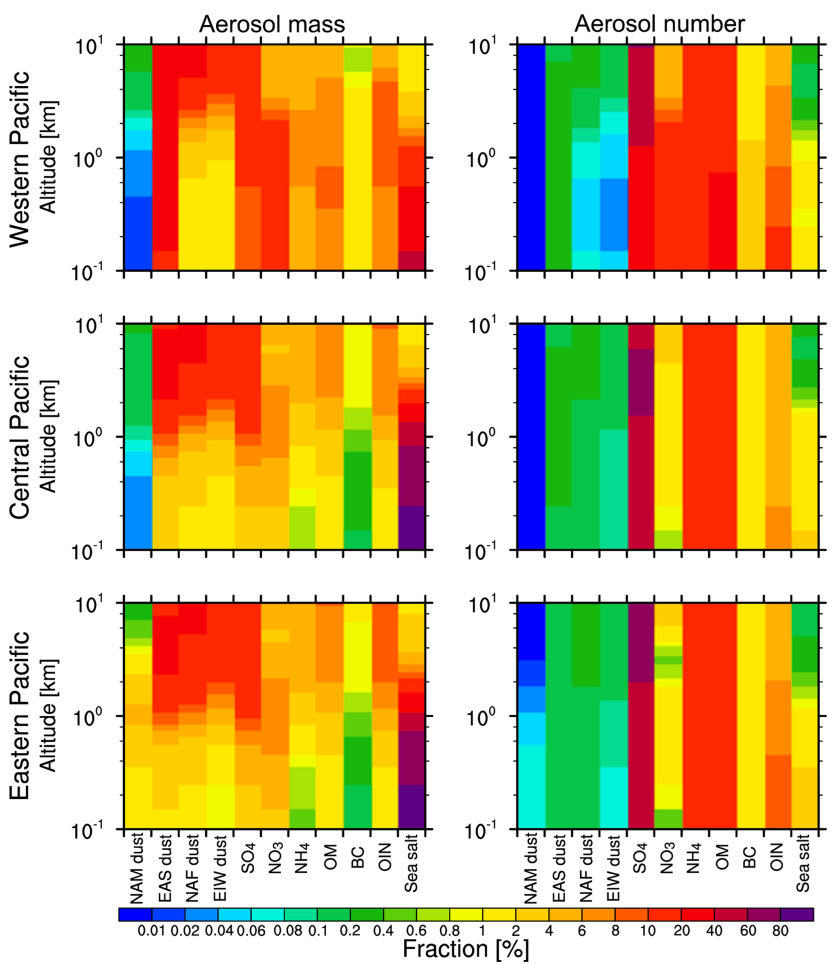

Figure 6. Vertical distribution of fractional contributions to aerosol composition mass and number over the western, central, and eastern Pacific from the WRF-Chem simulation averaged for 2010-2014.

from Yu et al. (2008). Because this comparison is complicated by differences in the time period, the discrepancies may be due to the larger variabilities of aerosols over East Asia. However, the dust mass flux is $60 \%$ smaller than the MODIS-CALIOP-estimated in 2008 (Yu et al., 2012). The discrepancy may be due to the different years and vertical distributions of the dust and wind vectors. Also, Yu et al. (2015) noted that there is a $\pm 45 \%-70 \%$ dust mass flux uncertainty from the satellite estimate.

For a more detailed dust comparison, the contributions of three major dust sources to the total aerosol mass are also analyzed (Fig. 8). The exported dust mass fluxes from EAS, NAF, and EIW are about 21.5, 15.2, and $12.1 \mathrm{Tg}^{\text {year }}{ }^{-1}$, which are about $26.5 \%, 18.8 \%$, and $14.9 \%$ of the total aerosol mass flux. After trans-Pacific transport, about $21.0 \%$ of EAS dust, $29.6 \%$ of NAF dust, and $32.5 \%$ EIW dust arrive on the west coast of the US, where the NAF dust is the biggest contributor. Following dust, sulfate is another major composition in the exported and imported regions, and it contributes about $9.5 \mathrm{Tg} \mathrm{year}^{-1}(11.7 \%)$ and $3.8 \mathrm{Tg}_{\text {year }}{ }^{-1}$ $(14.2 \%)$, respectively. Other polluting aerosols (e.g., nitrate, ammonium, organic matter, black carbon, other inorganic matter) are also exported from East Asia (about 16.9 $\mathrm{Tg}_{\text {year }}{ }^{-1}$ ), transported across the North Pacific (about 11.0 $\mathrm{Tg}_{\mathrm{gear}}{ }^{-1}$ ), and imported into North America (about
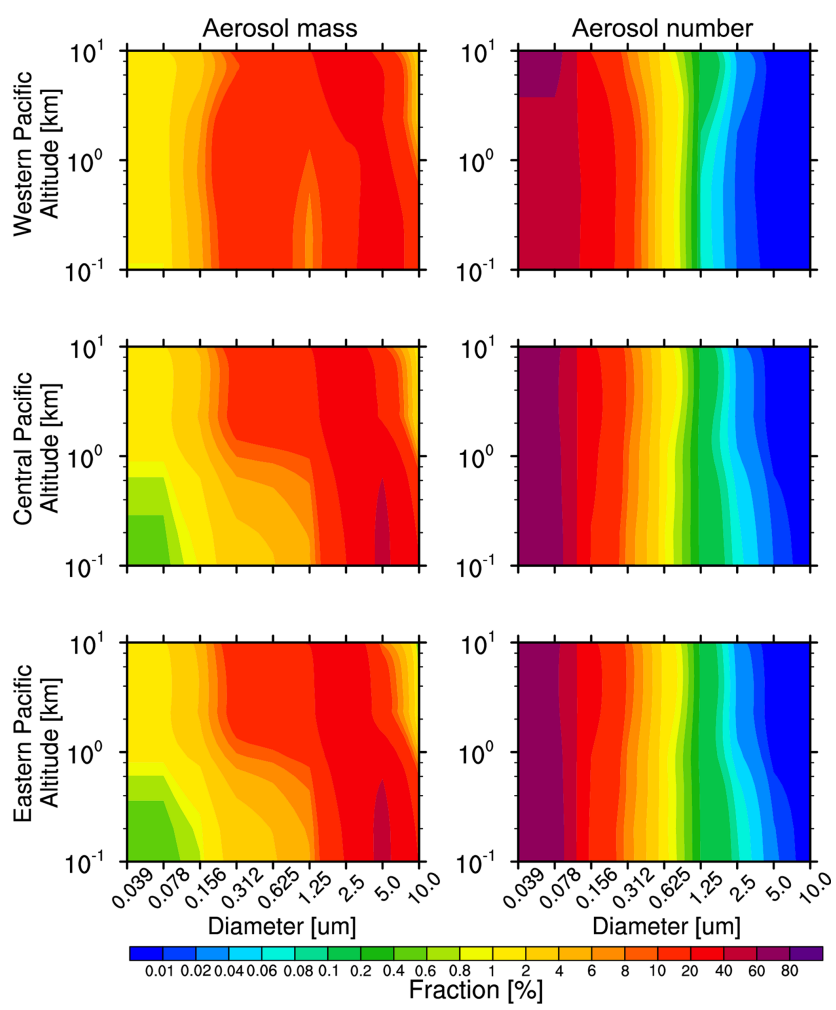

Figure 7. Vertical distribution of fractional contributions to the size of aerosol mass and number over the western, central, and eastern Pacific from the WRF-Chem simulation averaged for 2010-2014.

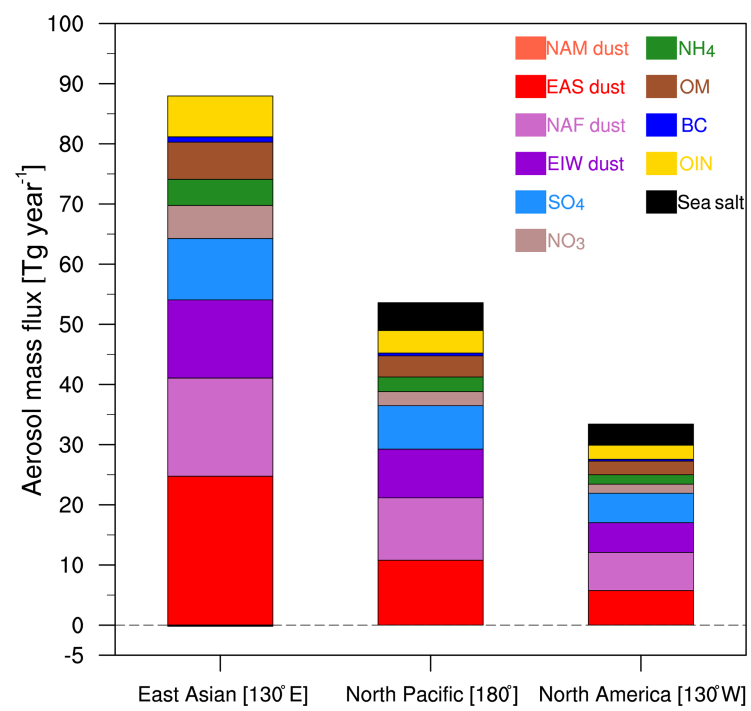

Figure 8. Model-based estimate of aerosol annual mass flux in East Asian outflow, across the North Pacific and North America inflow from the WRF-Chem simulation averaged for 2010-2014.

6.5 $\mathrm{Tg}$ year $^{-1}$ ). Here, sea salt is not included in the polluting aerosols as it is produced from the North Pacific.

Previous studies showed that the seasonal variations of trans-Pacific transport aerosols are determined by the me- 

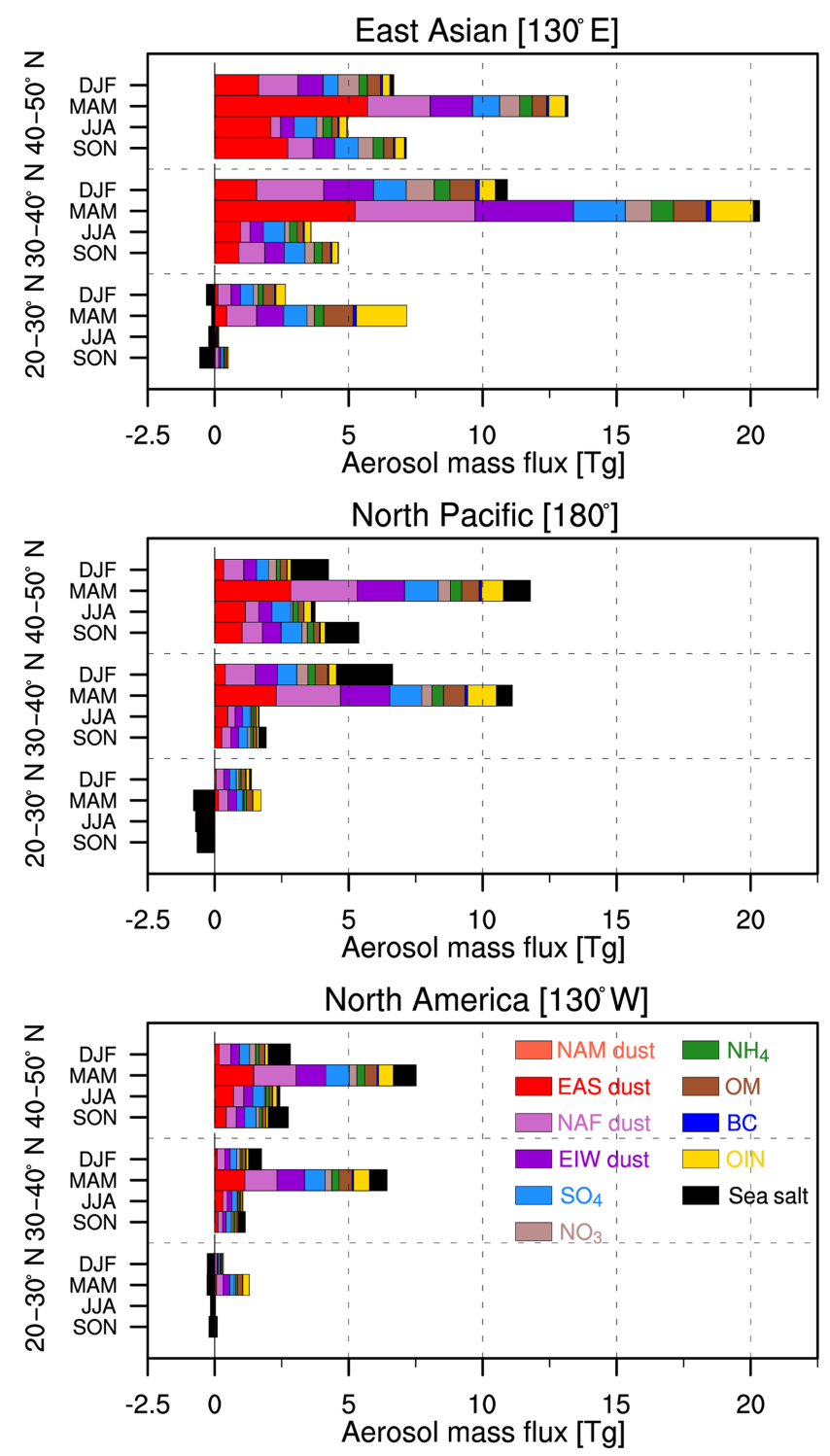

Figure 9. Meridional variations of East Asian outflow across the North Pacific and North American inflow of aerosol seasonal mass flux for 2010-2014.

teorological conditions, emissions, chemistry, and wet/dry deposition processes (Yu et al., 2008; Hu et al., 2016). However, few studies focused on the seasonal variations of aerosol compositions along the trans-Pacific pathway. Figure 9 shows the seasonal variations of meridionally integrated aerosol compositional mass flux for 2010-2014 across East Asia $\left(130^{\circ} \mathrm{E}\right)$, North Pacific $\left(180^{\circ}\right)$, and North America $\left(130^{\circ} \mathrm{W}\right)$, contributed by dust, sulfate, nitrate, ammonium, organic matter, black carbon, other inorganic matter, and sea salt. For the East Asian outflow, the highest aerosol mass flux of $39.8 \mathrm{Tg}$ year $^{-1}$ is within the $30-40^{\circ} \mathrm{N}$ segment, followed by $32.0 \mathrm{Tg}$ year $^{-1}$ in the $40-50^{\circ} \mathrm{N}$ segment, and $9.3 \mathrm{Tg}_{\text {year }}{ }^{-1}$ in the $20-30^{\circ} \mathrm{N}$ segment. The NAF dust with the mass flux of $1.8 \mathrm{Tg}_{\text {year }}{ }^{-1}$ dominates the total aerosol mass in the $20-30^{\circ} \mathrm{N}$ subtropical segment, and the EAS dust with the mass flux of $1.2 \mathrm{Tg}$ year $^{-1}$ dominates in the $40-50^{\circ} \mathrm{N}$ segment. In the $30-40^{\circ} \mathrm{N}$ segment, the EAS dust, NAF dust, and EIW dust contribute about 8.7, 8.3, and $6.8 \mathrm{Tg}$ year $^{-1}$, respectively. The total aerosol mass flux peaks in MAM over the three meridional segments followed by DJF, because of stronger springtime dry convection over East Asia (Dickerson et al., 2007) and stronger and more frequent warm conveyor belts (WCBs) in spring and winter (Eckhardt et al., 2004). The dust (about 25.6 Tg) exported from East Asia can contribute up to $63.1 \%$ to the total aerosol mass concentration in MAM, in which the EAS dust is the greatest contributor, about $28.1 \%(11.4 \mathrm{Tg})$. In addition to dust, the aerosols are mainly composed of anthropogenic pollution and biomass burning particles, about $36.3 \%$ (14.7 Tg), in which the OIN is the greatest contributors, about $10.0 \%$ $(4.1 \mathrm{Tg})$. For example, the maximum BC and OM in MAM indicates that the strongest biomass burning occurs in MAM (Giglio et al., 2006; Bian et al., 2007).

Over the North Pacific region, the aerosol mass flux reduces to about $38.5 \%$ (DJF), $42.3 \%$ (MAM), $47.6 \%$ (JJA), and $43.3 \%$ (SON), compared with aerosols from East Asia. In DJF, the NAF dust (about 2.2 Tg) and EIW dust (about $1.5 \mathrm{Tg}$ ) are significantly greater than the EAS dust (about $0.8 \mathrm{Tg}$ ). The decreasing EAS dust could be attributed to its low altitude, so it can be removed much easier by rain. Sea salt in the North Pacific is more abundant than in other subregions, with a maximum value in DJF.

For the west coast of the US inflow, the aerosol mass flux accounts for about $8.8 \%\left(0.8 \mathrm{Tg}\right.$ year $\left.^{-1}\right), 26.3 \%$ $\left(10.4 \mathrm{Tg} \mathrm{year}^{-1}\right)$, and $48.5 \%\left(15.5 \mathrm{Tg}_{\text {year }}{ }^{-1}\right)$ in the $20-30$, $30-40$, and $40-50^{\circ} \mathrm{N}$ segments compared with the outflow. Aerosol mass flux in the $40-50^{\circ} \mathrm{N}$ segment is greater than that in the $30-40^{\circ} \mathrm{N}$ segment because of the poleward shift of aerosols during the trans-Pacific transport (Yu et al., 2008). As the dominating aerosol composition, trans-Pacific dust is about $7.6 \mathrm{Tg}$ year $^{-1}$ in the $40-50^{\circ} \mathrm{N}$ segment, in which the EAS dust, NAF dust, and EIW dust are about 2.8, 2.8, and $2.1 \mathrm{Tg}_{\text {year }}{ }^{-1}$, respectively. Also, we can see that larger change of aerosol mass flux occurs in the $30-40^{\circ} \mathrm{N}$ segment, and smaller change occurs in the $40-50^{\circ} \mathrm{N}$ segment. In the $20-30^{\circ} \mathrm{N}$ segment, aerosols from North America have a westward transport (negative flux) in JJA and SON, because of the westward transport of sea salt aerosol. This phenomenon is also shown by Yu et al. (2008). Overall, 36.1\% (7.6 $\mathrm{Tg}_{\text {year }}{ }^{-1}$ ) of the trans-Pacific transport dust and $51.3 \%$ (5.4 $\mathrm{Tg}$ year $^{-1}$ ) of pollution aerosols arrive in North America in the $40-50^{\circ} \mathrm{N}$ segment. For the $30-40^{\circ} \mathrm{N}$ segment, the contributions are $21.1 \%\left(5.0 \mathrm{Tg}\right.$ year $\left.^{-1}\right)$ for the dust and $26.3 \%$ (4.0 $\mathrm{Tg}_{\text {year }^{-1}}$ ) for the pollution, respectively. In MAM and JJA, dust is the major contributor, followed by sulfate. However, in DJF and SON, sea salt is the major contributor, followed by dust. For the pollution aerosols, sulfate is the major contributor, which is about $3.8 \mathrm{Tg}$ year $^{-1}(14.2 \%$ to total aerosol mass). Additionally, the aerosol transport efficiency 
(aerosol mass flux arriving into North America vs. that leaving East Asia) is about $34 \%$ at the annual timescale, with a peak value of $40 \%$ in JJA, in which the transport efficiency of dust is in $41 \%$ in JJA, while the transport efficiency of the pollution aerosol (included sulfate, nitrate, organic matter, black carbon, and ammonium) is $43 \%$ in MAM (Fig. S1 in the Supplement).

In general, aerosols in the $30-50^{\circ} \mathrm{N}$ segment contribute about $48.8 \%$ of dust to the total aerosol mass. The pollution aerosol contribution is smaller in the $30-50^{\circ} \mathrm{N}$ segment compared with dust, but it is the opposite in the $20-30^{\circ} \mathrm{N}$ segment. This is attributed to outflow aerosols occurring mainly in the $30-50^{\circ} \mathrm{N}$ segment, especially associated with dust (Fig. 1). Also, the smallest mass concentration in the 20$30^{\circ} \mathrm{N}$ segment is likely to result from the shift of westerlies to easterlies in the free troposphere (Yu et al., 2008). Significantly, the dust in the $20-30^{\circ} \mathrm{N}$ segment from the Middle East and central Asia and north Africa is about 2 times that of the dust from East Asia. During the transport over Pacific Ocean, the aerosols rapidly decrease in the $20-40^{\circ} \mathrm{N}$ segment because of wet deposition induced by precipitation (Hu et al., 2016). The annual mean of dust flux inflow to North America is about $13.4 \mathrm{Tg}_{\text {year }}{ }^{-1}$, and the proportion is about $50.1 \%$. This is followed by sulfate, with a flux of about $3.8 \mathrm{Tg}$ year $^{-1}(14.2 \%)$. It is obvious that dust is the major natural aerosols and sulfate is the major anthropogenic aerosols in the trans-Pacific transport.

\subsection{Aerosol direct radiative forcing}

Clearly, the AOD and absorbing AOD (AAOD) over East Asia, the North Pacific, and the west coast of North America are dominated by the transported aerosol, while the AOD and AAOD over eastern North America are dominated by North American aerosol. Also, the SSA from transported aerosol is larger than that from North American aerosol over North America (except the northeastern region of North America) (Fig. S2). Therefore, the transported aerosol causes much larger direct radiative forcing. In order to understand the radiative effect of aerosols, the spatial distribution of aerosol compositional direct radiative forcing averaged for 20102014 at TOA, in the atmosphere (ATM), and at the SFC under all-sky conditions for the net (shortwave plus longwave) radiation is shown in Fig. 10. The spatial distribution of aerosol compositional direct radiative forcing closely follows the corresponding aerosol compositional mass. At the SFC, all aerosol compositions reduce direct radiative fluxes and result in cooling effect from the trans-Pacific transport. It is interesting to note that the black carbon mass is a relatively small (about $0.83 \%$ contribution to total aerosol mass), but it causes larger cooling effect at the SFC, especially over India and southeast China, with the largest forcing value of $-8 \mathrm{~W} \mathrm{~m}^{-2}$. The maximum dust direct radiative forcing at the SFC is dominated over the Taklimakan, Gobi Desert, and Arabian Sea with negative value of about $-6 \mathrm{~W} \mathrm{~m}^{-2}$. This
Table 1. Annual mean radiative forcing of aerosols simulated by WRF-Chem for 2010-2014 over three regions shown in Fig. 2. Negative values represent downward radiation. Units: $\mathrm{W} \mathrm{m}^{-2}$.

\begin{tabular}{lrrr}
\hline & TOA & ATM & SFC \\
\hline Western Pacific & -4.08 & 5.36 & -9.44 \\
Central Pacific & -2.82 & 2.07 & -4.89 \\
Eastern Pacific & -2.28 & 1.40 & -3.68 \\
\hline
\end{tabular}

pattern is consistent with the result from Zhao et al. (2013b) and is inside the range of $-5.2-15.6 \mathrm{~W} \mathrm{~m}^{-2}$ from $\mathrm{Bi}$ et al. (2013) and Huang et al. (2014). In the ATM, aerosol compositions lead to a warming effect, with black carbon inducing the largest warming of about $+8 \mathrm{~W} \mathrm{~m}^{-2}$, and the dust and sulfate direct radiative forcing is surprisingly much smaller even though they have larger mass. This can be attributed to the strongest absorbing property of black carbon (Bond et al., 2013). Dust produces a warming effect with a maximum value of about $+2.0 \mathrm{~W} \mathrm{~m}^{-2}$ and a domain average of $+0.13 \mathrm{~W} \mathrm{~m}^{-2}$ in the ATM. Over the western, central, and eastern Pacific, the dust and $\mathrm{BC}$ radiative forcing is ranged from +0.1 to $+0.4 \mathrm{~W} \mathrm{~m}^{-2}$ and +1 to $+8 \mathrm{~W} \mathrm{~m}^{-2}$, respectively, which is well consist with the results of global model simulations with a range of +0.2 to $+0.4 \mathrm{~W} \mathrm{~m}^{-2}$ (Klingmüller et al., 2019) and +1 to $+7.5 \mathrm{~W} \mathrm{~m}^{-2}$ (Jones et al., 2007; Bond et al., 2013). At the TOA, dust, sulfate, organic matter, and other aerosol result in cooling, but black carbon results in warming with the highest value of $+8.0 \mathrm{~W} \mathrm{~m}^{-2}$ over India and southeast China. Overall, black carbon results in a significant cooling effect at the SFC and warming effect in the ATM and at the TOA. Dust also causes a significant cooling effect at the SFC and TOA.

Figure 11 shows the seasonal variation of aerosol direct radiative forcing over the three subregions (trans-Pacific transport path) under all-sky conditions. The direct radiative forcing of the five aerosol compositions is large in MAM due to high concentrations of pollution aerosols and dust along the trans-Pacific transport pathway. The forcing maximum is produced by black carbon especially in the ATM, even though black carbon mass is lowest in the total aerosol mass. The seasonal variations of direct radiative forcing are consistent with that of the aerosol column mass (Fig. 9). Over the western Pacific, black carbon results in a surface cooling of -4.43 to $1.84 \mathrm{~W} \mathrm{~m}^{-2}$, atmosphere warming of +2.61 to $+6.80 \mathrm{~W} \mathrm{~m}^{-2}$, and TOA cooling of +0.76 to $+2.38 \mathrm{~W} \mathrm{~m}^{-2}$. Dust results in a surface cooling of -3.10 to $0.92 \mathrm{~W} \mathrm{~m}^{-2}$, atmosphere warming of +0.02 to $+0.61 \mathrm{~W} \mathrm{~m}^{-2}$, and TOA cooling of -2.48 to $0.91 \mathrm{~W} \mathrm{~m}^{-2}$. During the trans-Pacific transport, the direct radiative forcing rapidly decreases as aerosols are deposited. Over the eastern Pacific, BC results in a surface cooling of -1.79 to $0.42 \mathrm{~W} \mathrm{~m}^{-2}$, atmosphere warming of +0.61 to $+2.75 \mathrm{~W} \mathrm{~m}^{-2}$, and TOA cooling of +0.19 to $+0.96 \mathrm{~W} \mathrm{~m}^{-2}$. Dust results in a surface 
TOA
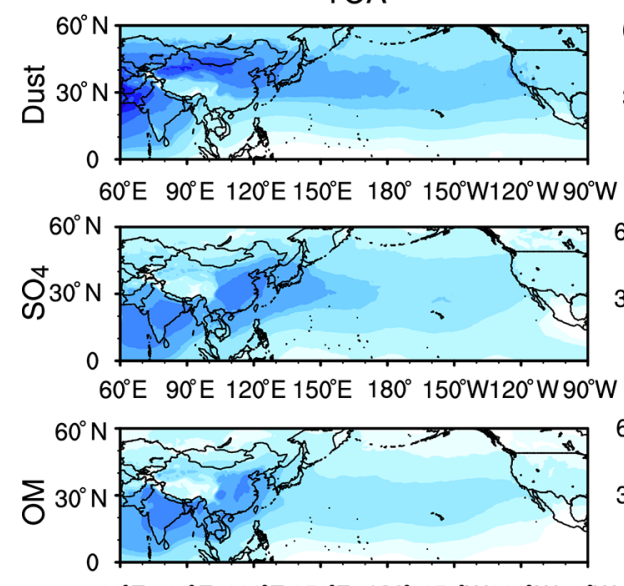

$60^{\circ} \mathrm{E} 90^{\circ} \mathrm{E} 120^{\circ} \mathrm{E} 150^{\circ} \mathrm{E} 180^{\circ} 150^{\circ} \mathrm{W} 120^{\circ} \mathrm{W} 90^{\circ} \mathrm{W}$
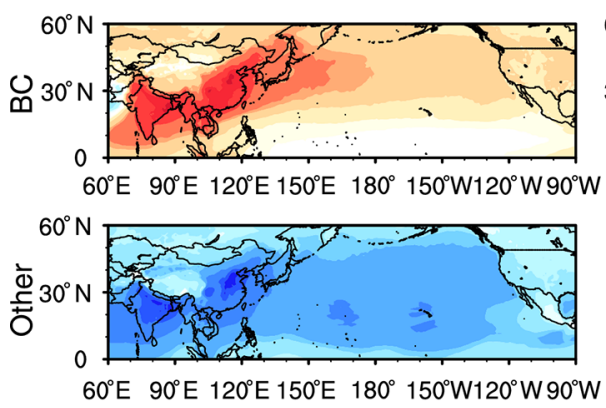

ATM

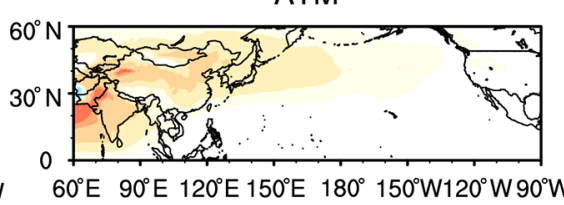

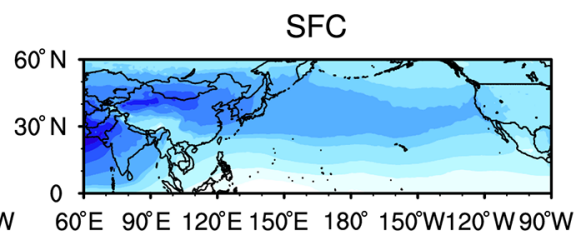

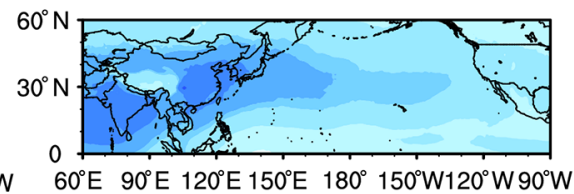

$60^{\circ} \mathrm{E} 90^{\circ} \mathrm{E} 120^{\circ} \mathrm{E} 150^{\circ} \mathrm{E} 180^{\circ} 150^{\circ} \mathrm{W} 120^{\circ} \mathrm{W} 90^{\circ} \mathrm{W}$
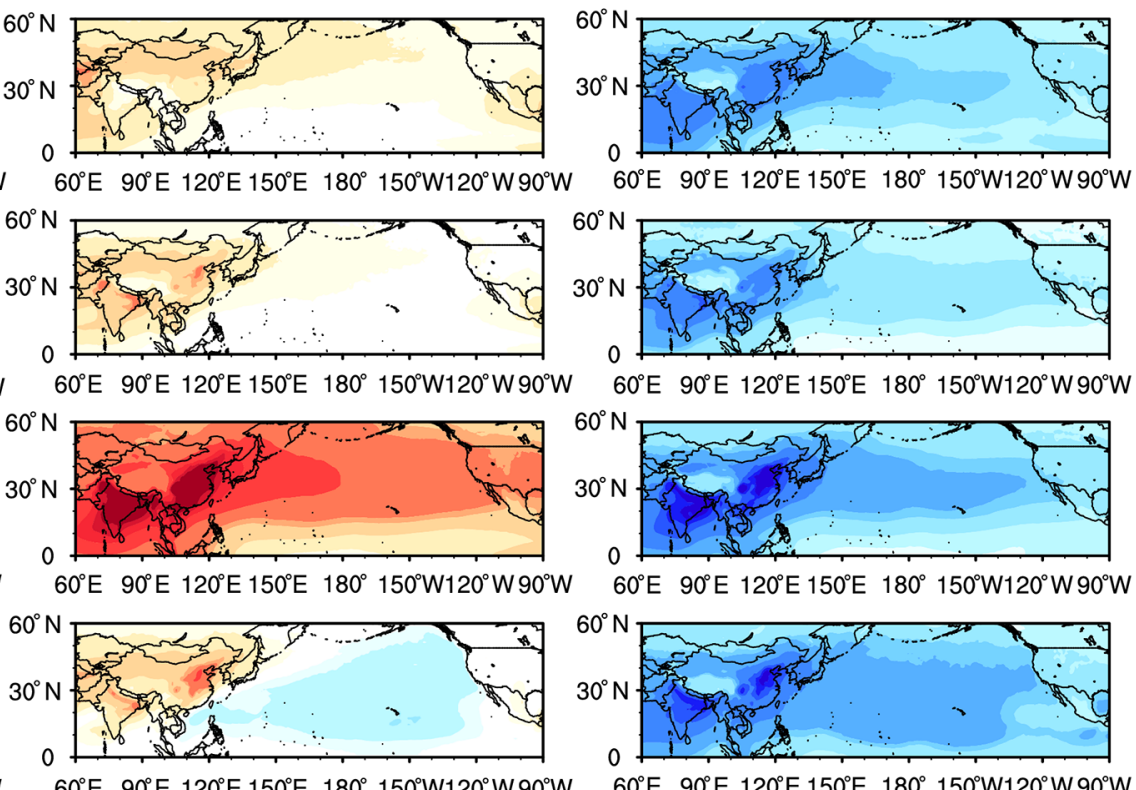

$60^{\circ} \mathrm{E} 90^{\circ} \mathrm{E} 120^{\circ} \mathrm{E} 150^{\circ} \mathrm{E} 180^{\circ} 150^{\circ} \mathrm{W} 120^{\circ} \mathrm{W} 90^{\circ} \mathrm{W}$
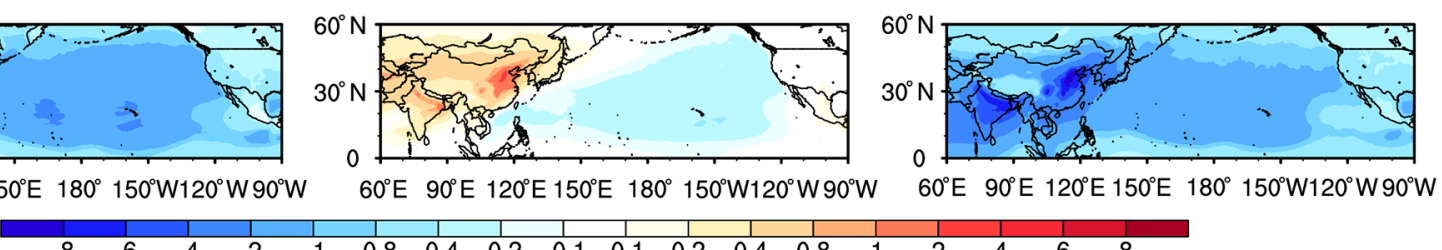

$60^{\circ} \mathrm{E} 90^{\circ} \mathrm{E} 120^{\circ} \mathrm{E} 150^{\circ} \mathrm{E} 180^{\circ} 150^{\circ} \mathrm{W} 120^{\circ} \mathrm{W} 90^{\circ} \mathrm{W}$

$60^{\circ} \mathrm{E} 90^{\circ} \mathrm{E} 120^{\circ} \mathrm{E} 150^{\circ} \mathrm{E} 180^{\circ} 150^{\circ} \mathrm{W} 120^{\circ} \mathrm{W} 90^{\circ} \mathrm{W}$

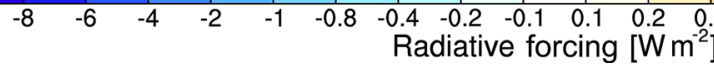

Figure 10. Spatial distribution of aerosol composition direct radiative forcing at the TOA (left), in the atmosphere (ATM) (middle), and at the SFC (right) under all-sky conditions from the WRF-Chem simulation averaged for 2010-2014. The other compositions induce ammonium, nitrate, sea salt, and unspeciated $\mathrm{PM}_{2.5}$.

cooling of -1.72 to $-0.34 \mathrm{~W} \mathrm{~m}^{-2}$, atmosphere warming of +0.005 to $+0.13 \mathrm{~W} \mathrm{~m}^{-2}$, and TOA cooling of -1.59 to $0.32 \mathrm{~W} \mathrm{~m}^{-2}$. The annual mean direct radiative forcing of aerosols over the three subregions is also shown in Table 1. The trans-Pacific transport aerosols result in a surface cooling of $-3.68 \mathrm{~W} \mathrm{~m}^{-2}$, atmosphere warming of $+1.40 \mathrm{~W} \mathrm{~m}^{-2}$, and TOA cooling of $-2.28 \mathrm{~W} \mathrm{~m}^{-2}$.

\subsection{Impact of trans-Pacific transport over the US}

\subsubsection{Mass versus number concentrations}

Aerosols can reach and influence the North American environment and regional climate through trans-Pacific transport (Chin et al., 2007; Yu et al., 2012; Huang et al., 2014; $\mathrm{Hu}$ et al., 2016). Figure 12 shows the spatial distribution of source contribution of trans-Pacific transport and North American local aerosol mass integrated in the atmospheric column and at the surface. To better describe the contribution from the two sources, North America is divided into three subregions: west $\left(130-110^{\circ} \mathrm{W}\right)$, central $\left(110-90^{\circ} \mathrm{W}\right)$, and east $\left(90-70^{\circ} \mathrm{W}\right)$. Clearly, the aerosol mass over the ocean near North America is dominated by the trans-Pacific transport (more than $90 \%$ contribution). However, over the continent, aerosols from North America have significant contributions. In the atmospheric column, aerosols from transPacific transport have a larger contribution than those from the US, except for the Nevada desert region, where a large amount of dust can be emitted. Over this desert region, the local source contribution is about $60 \%$ compared to about $40 \%$ from trans-Pacific transport. Other than this region, the continental North American is mainly influenced by transported aerosols (about 50\%-60\%). Unlike the source contribution of column aerosol mass, the surface aerosol mass contribution mainly comes from local emission, which can reach more than $60 \%$. Hence, surface air quality over North America is mainly influenced by local sources including pollution aerosols and dust. At the higher altitude, the transported aerosols are the major particles, which can influence clouds (Zhao et al., 2012) and radiative forcing (Yu et al., 2012).

Figure 13 shows the seasonal and annual variation of transPacific transport and North American total aerosol mass fractional in the column and at the surface over the three sub- 

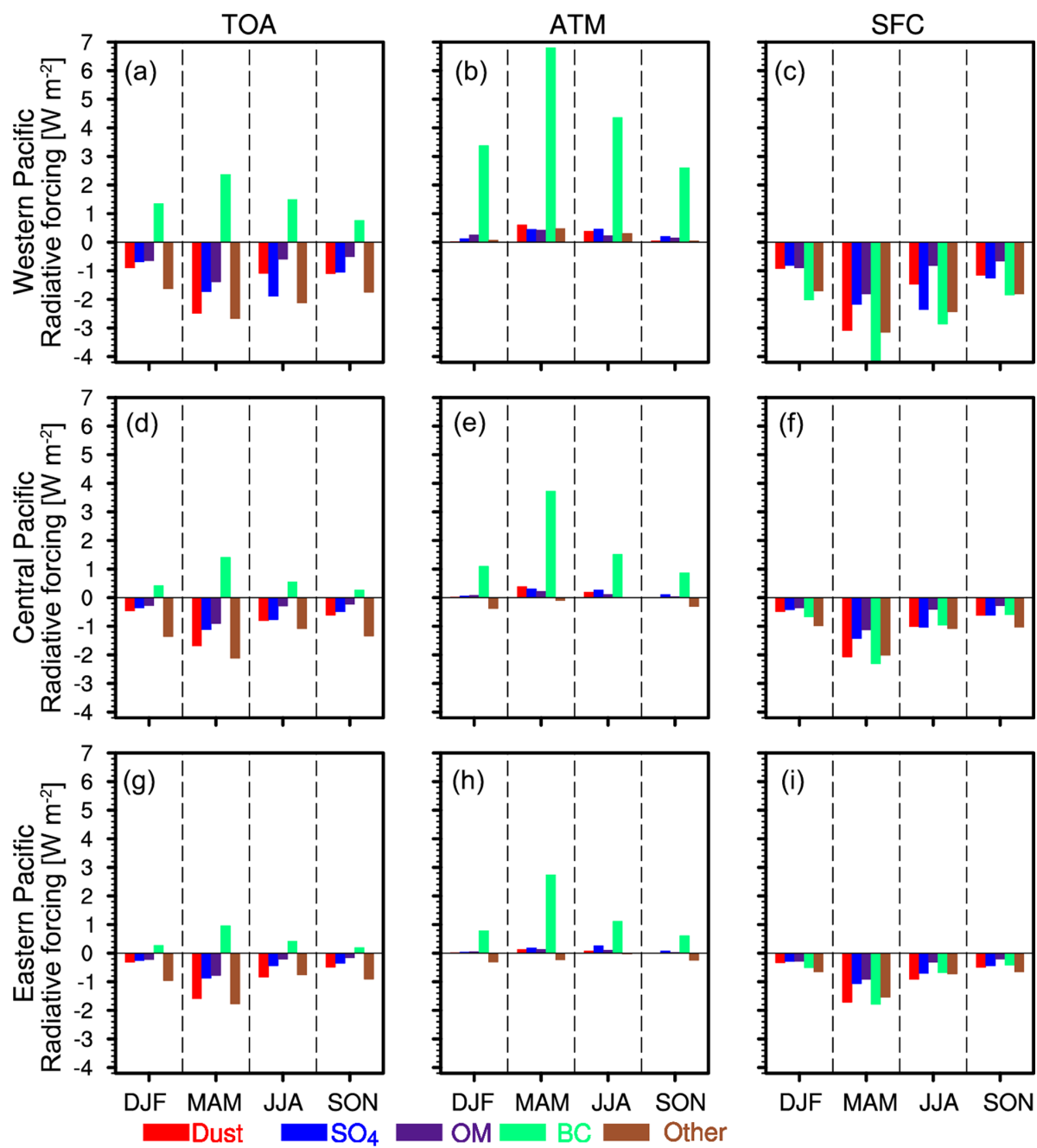

Figure 11. Seasonal variation of aerosol composition radiative forcing at the TOA (a, d, g), in the atmosphere (b, e, h), and at the surface (c, f, i) over the western, central, and eastern Pacific under all-sky conditions from the WRF-Chem simulation averaged for 2010-2014.

regions of North America. For the west, pollution aerosols and dust from transport have important contributions in the column (more than $60 \%$ ). At the surface, sea salt is dominated aerosols from transport, followed by local dust, with similar fractions seasonally. The annual mean of dust in the column is about $34.7 \%$ and sea salt at the surface is about $44.6 \%$. Further away from the ocean, the influence of sea salt is reduced in the central region. The transported aerosols are about $65.4 \%$ (in the column) and $36.8 \%$ (at the surface) of the total, with a peak in MAM of $73.3 \%$ (in the column) and $41.7 \%$ (at the surface). At the surface, we also can see that more than $35 \%$ of OIN and nitrate is contributed by the local source with the seasonality of nitrate opposite to that of sulfate. The maximum nitrate mass occurs in the cold season (DJF) because of the combined effects of vertical turbulent mixing and temperature (Zhao et al., 2013a; Hu et al., 2016). For the east, the aerosol contribution is similar with the west in the column. However, at the surface, there is lit- tle dust contribution from local sources year round, and the NAF dust dominates the transported aerosols through transAtlantic transport, especially in JJA (Yu et al., 2015). The NAF dust contributes about $27 \%$ (except sea salt) to the column and surface. The trans-Atlantic transport of dust is not discussed in this study, because it has been studied in most previous works (e.g., Dunion and Velden, 2004; Mahowald et al., 2008; Wilcox et al., 2010; Yu et al., 2015)

Figure 14 shows the seasonal and annual variations of trans-Pacific transport and North American total fractional aerosol number concentration in the column and at the surface. In the column, long-range-transported aerosols have a significant influence on the aerosol number concentration over the US. The maximum contribution is $80 \%$ over the western, followed by $52.7 \%$ over the central, and $51.4 \%$ over the eastern regions. However, the small particles are above the planetary boundary layer, so the maximum aerosol number concentration occurs in DJF at the surface, which is 

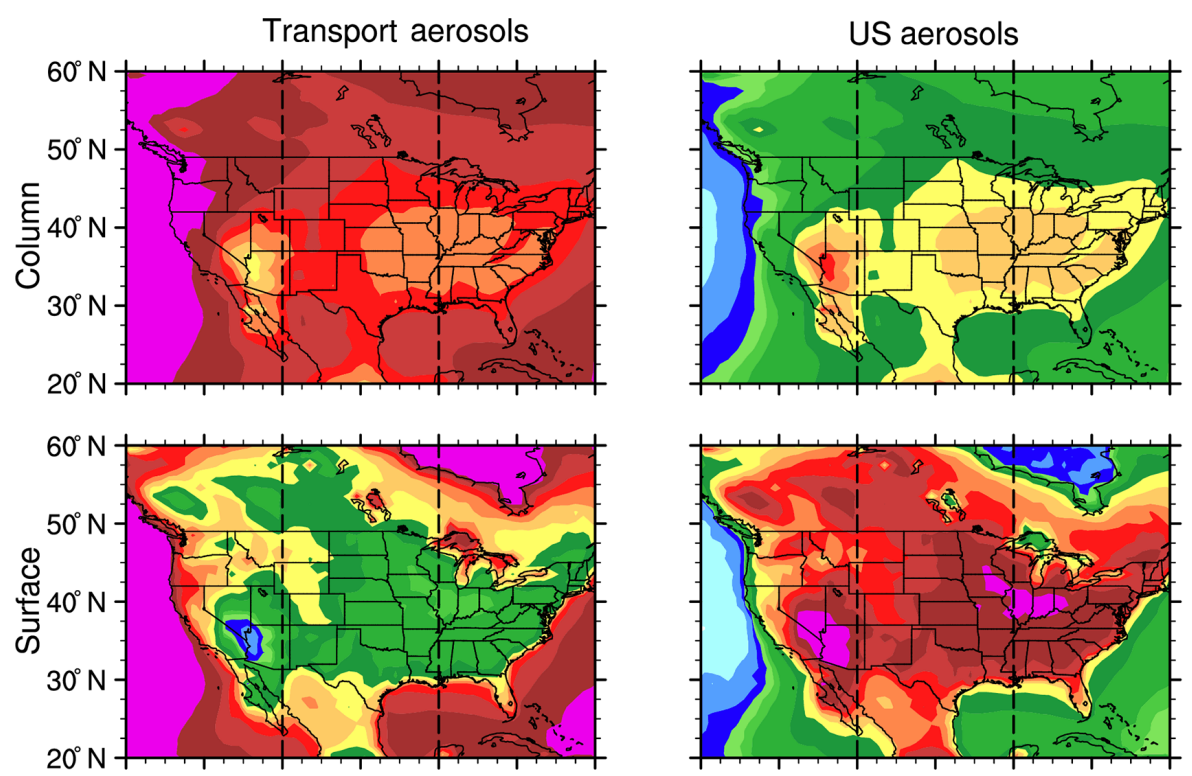

$130^{\circ} \mathrm{W} 120^{\circ} \mathrm{W} 110^{\circ} \mathrm{W} 100^{\circ} \mathrm{W} 90^{\circ} \mathrm{W} 80^{\circ} \mathrm{W} 70^{\circ} \mathrm{W} 130^{\circ} \mathrm{W} 120^{\circ} \mathrm{W} 110^{\circ} \mathrm{W} 100^{\circ} \mathrm{W} 90^{\circ} \mathrm{W} 80^{\circ} \mathrm{W} 70^{\circ} \mathrm{W}$

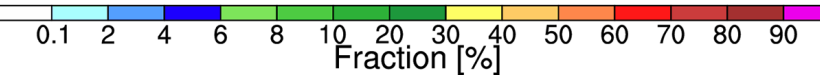

Figure 12. Spatial distribution of trans-Pacific transport and US total aerosol mass fraction for the column and at the surface from the WRFChem simulations averaged for 2010-2014. The North American region is divided into three subregions bounded by the dotted lines: west $\left(20-60^{\circ} \mathrm{N}\right.$ and $\left.130-110^{\circ} \mathrm{W}\right)$, central $\left(20^{\circ} \mathrm{W}-60^{\circ} \mathrm{N}\right.$ and $\left.110-90^{\circ} \mathrm{W}\right)$, and east $\left(20-60^{\circ} \mathrm{N}\right.$ and $\left.90-70^{\circ} \mathrm{W}\right)$.

consistent with the aerosol mass. At the surface, the transPacific aerosols contribute about $44.3 \%$ of number concentration over the western, followed by $17.2 \%$ over the central, and $16.3 \%$ over the eastern regions. Also, we can see that nitrate from local sources has a maximum contribution in DJF and minimum contribution in JJA. In general, surface aerosol particles are mainly from local emissions over the central and eastern regions, especially for pollution aerosols. This is consistent with a previous study claiming that local emissions of North America dominated the eastern US surface pollution particles (Chin et al., 2007).

\subsubsection{Aerosol direct radiative forcing}

Figure 15 shows the seasonal and annual variation of fractional contribution from trans-Pacific (red) and North American local emitted (blue) aerosols to the total direct radiative forcing at the TOA, in the ATM, and at the SFC. The contribution from trans-Pacific aerosols has a seasonal variation, with a peak in MAM due to the strongest transport of aerosols. Also, the trans-Pacific aerosol produces the largest forcing effect over western North America (dominated by trans-Pacific transport), followed by eastern North America (dominated by trans-Atlantic transport). Overall, aerosols result in TOA cooling, atmosphere warming, and surface cooling. Over the western region, because of the local dust aerosol with little forcing, the transported aerosol can produce annual mean direct radiative forcing of -2.91
(SFC, 86.4\%), +1.36 (ATM, 85.5\%), and -1.55 (TOA, $87.1 \%) \mathrm{W} \mathrm{m}^{-2}$. The minimum total direct radiative forcing occurs in JJA at the TOA, when strong wet deposition results in aerosol mass reduction. The direct radiative forcing ranges from -2.99 to $-0.87 \mathrm{~W} \mathrm{~m}^{-2}$ from transported aerosols and -0.43 to $-0.10 \mathrm{~W} \mathrm{~m}^{-2}$ from North American aerosols. In the ATM, the forcing ranges from +0.57 to $+2.69 \mathrm{~W} \mathrm{~m}^{-2}$ and +0.10 to $+0.29 \mathrm{~W} \mathrm{~m}^{-2}$ for the transported and North American aerosols, respectively. Generally, the forcing at the surface is larger, which ranges from -5.68 to $-1.48 \mathrm{~W} \mathrm{~m}^{-2}$ from the transported aerosols and -0.72 to $-0.20 \mathrm{~W} \mathrm{~m}^{-2}$ from the North American aerosols. Compared with the western North American region, the eastern US has more pollution aerosols emitted locally and less aerosols transported remotely (Chin et al., 2007). Therefore, Fig. 15 shows a significant increase of the direct radiative forcing from North American aerosol over the central and eastern regions. The pattern is similar, with a peak in MAM at TOA and surface, but for the atmosphere a peak occurs in JJA. The direct radiative forcing induced by the transported aerosols ranges from -3.98 to $-1.11 \mathrm{~W} \mathrm{~m}^{-2}\left(-4.30\right.$ to $\left.-1.02 \mathrm{~W} \mathrm{~m}^{-2}\right)$ at the $\mathrm{SFC},+0.37$ to $+2.48 \mathrm{~W} \mathrm{~m}^{-2}\left(+0.54\right.$ to $\left.+2.25 \mathrm{~W} \mathrm{~m}^{-2}\right)$ in the ATM, and -2.04 to $-0.74 \mathrm{~W} \mathrm{~m}^{-2}\left(-2.04\right.$ to $\left.-0.48 \mathrm{~W} \mathrm{~m}^{-2}\right)$ at the TOA over the eastern (central) region. 

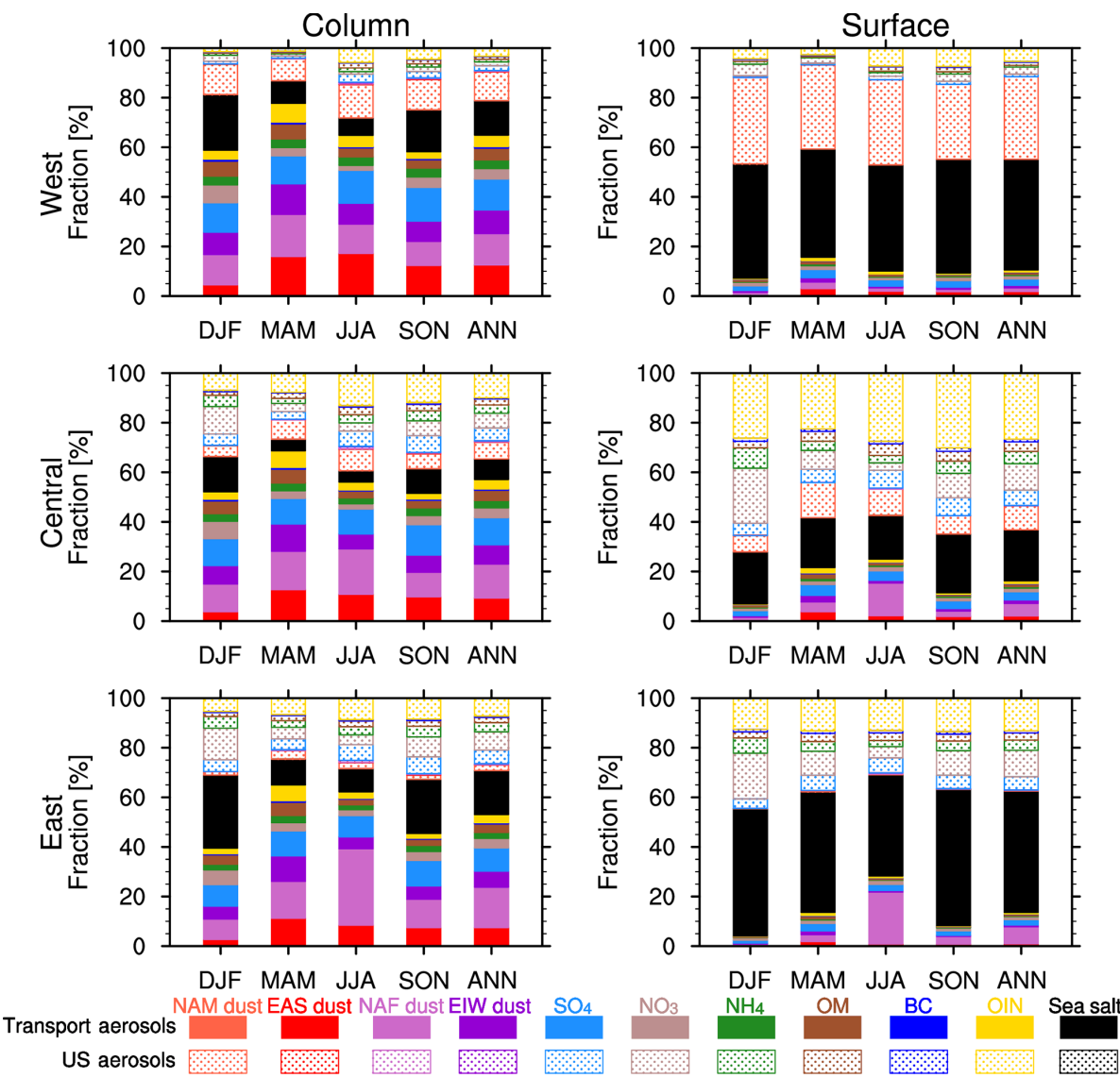

Figure 13. Seasonal and annual variation of trans-Pacific transport and US total aerosol mass fractional contribution for the column and at the surface from the WRF-Chem simulations averaged for 2010-2014 in the western, central, and eastern North America shown in Fig. 12.

\section{Summary and conclusion}

In this study, the characteristics of trans-Pacific transport of aerosols and their source contributions are investigated using an updated version of WRF-Chem. To better describe the aerosol intercontinental transport, quasi-global simulations $\left(180^{\circ} \mathrm{W}-180^{\circ} \mathrm{E}\right.$ and $\left.70^{\circ} \mathrm{S}-75^{\circ} \mathrm{N}\right)$ are conducted for the period of 2010-2014 to capture the spatial distribution and seasonal variation of both mass and number for various aerosol species. The fluxes of mass composition and direct radiative forcing of aerosols during the trans-Pacific transport are further discussed. Finally, the source contributions of aerosol composition mass, number concentration, and direct radiative forcing are quantified over the US. Generally, the updated model can capture the spatiotemporal characteristics of precipitation, wind, aerosol extinction profiles, AOD, extinction Ångström exponent (EAE), AAOD, and surface aerosol mass concentrations compared with various reanalysis and observation data. Our results further show that the model can reproduce the spatiotemporal characteristics of trans-Pacific aerosols and the associated impacts on the regional surface air quality over the west coast of the US (Hu et al., 2016). Moreover, the WRF-Chem simulation using eight bins can better reproduce the distribution of aerosol size and number (Zhao et al., 2013b), giving more detailed information about the spatial distribution (horizontal and vertical) of aerosols and the aerosol trans-Pacific transport process. Quantitative analysis of aerosol source contribution, and direct radiative forcing provides more evidence of the impacts of aerosols transported from eastern Asia on the regional air quality and climate of the western US. Finally, the tracer-tagging technique (Wang et al., 2014) is shown to be a useful tool to study the contributions of dust particles emitted from four main desert sources (North America: $140-80^{\circ} \mathrm{W}, 15-50^{\circ} \mathrm{N}$; East Asia: $75-150^{\circ} \mathrm{E}, 25-50^{\circ} \mathrm{N}$; north Africa: $20^{\circ} \mathrm{W}-35^{\circ} \mathrm{E}, 0$ $40^{\circ} \mathrm{W}$; and Middle East and central Asia: other regions) and their contribution during transport of individual dust emissions over Pacific Ocean.

Aerosol mass exported from East Asia are dominated by dust particles, in which dust aerosols from north Africa, the Middle East and central Asia are carried to East Asia at high altitude (above $4 \mathrm{~km}$ ) and mixed with dust from the Taklimakan and Gobi deserts, then transported across the Pacific Ocean. The East Asian dust contributes about $28.3 \%\left(22.3 \mathrm{mg} \mathrm{m}^{-2}\right)$ to the total aerosol mass concentration, followed by north African dust $\left(11.0 \%, 8.7 \mathrm{mg} \mathrm{m}^{-2}\right)$ 

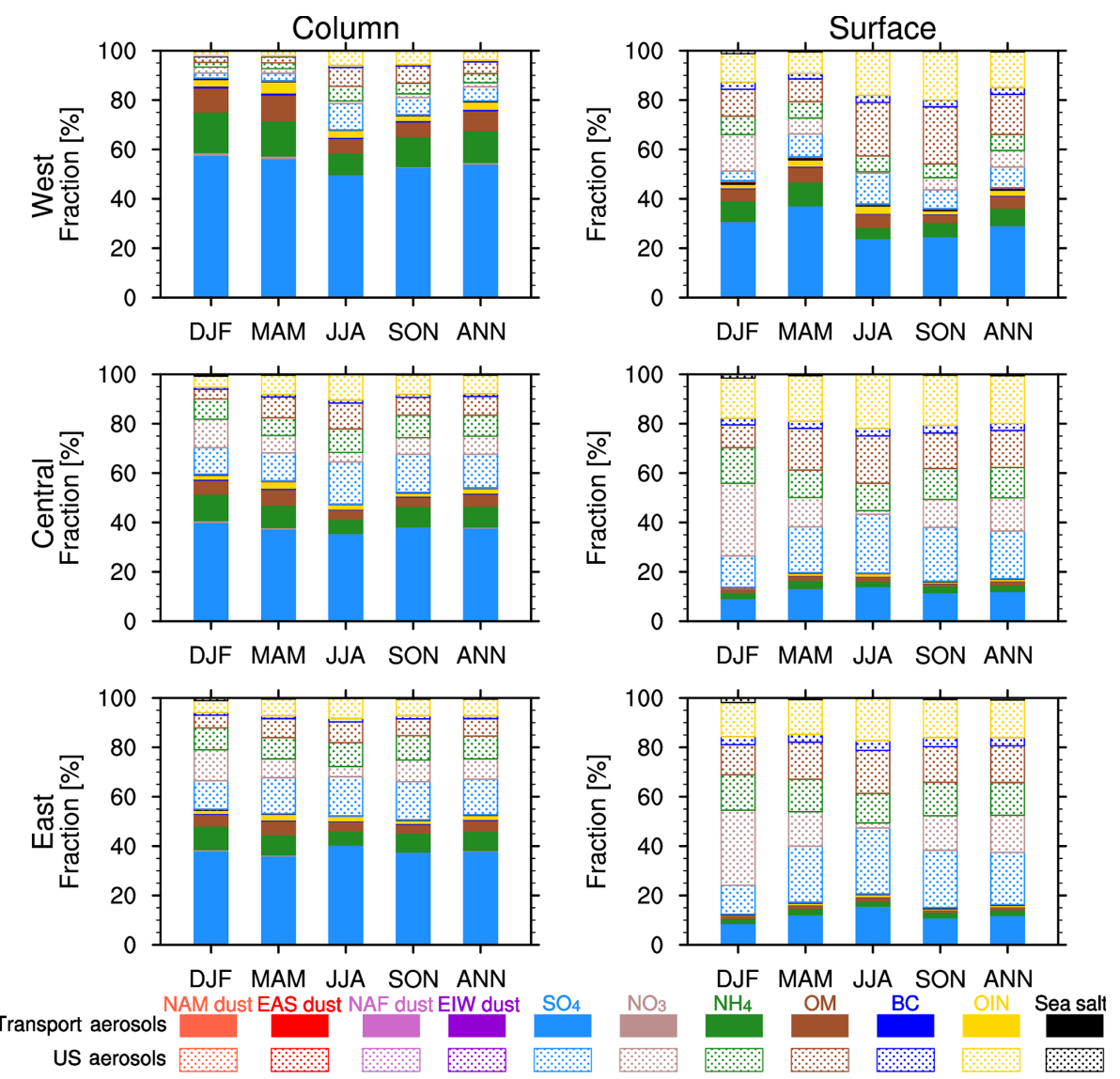

Figure 14. Same as in Fig. 13 but for aerosol number concentration.

and East Asian dust $\left(9.0 \%, 7.1 \mathrm{mg} \mathrm{m}^{-2}\right)$. During the transPacific transport, the aerosol mass concentration gradually decreases with higher concentration over East Asia (about $350 \mathrm{mg} \mathrm{m}^{-2}$ ) and dominates the total aerosol mass north of $30^{\circ} \mathrm{N}$ over the North Pacific due to strong westerly winds. Generally, the maximum aerosol mass concentration occurs below $4 \mathrm{~km}$, with about $15 \mu \mathrm{g} \mathrm{m}^{-3}$ in the $27-44^{\circ} \mathrm{N}$ segment in spring. Sea salt dominates the total aerosol mass along the Pacific Ocean below $1 \mathrm{~km}$ and dust dominates the total aerosols above $4 \mathrm{~km}$. Also, the aerosol plumes have an obvious poleward shift by the easterlies wind during the trans-Pacific transport. When imported into western North America, the transported dust contributes $41.1 \%$ to the total aerosol loading, followed by sea salt of about $21.7 \%$. The dust mass concentration from North America is $0.48 \mathrm{mg} \mathrm{m}^{-2}$, which is far lower than the East Asian dust (EAS, $4.8 \mathrm{mg} \mathrm{m}^{-2}$ ), north African dust (NAF, $4.6 \mathrm{mg} \mathrm{m}^{-2}$ ), and Middle eastern and central Asian dust (EIW, $3.6 \mathrm{mg} \mathrm{m}^{-2}$ ). Our results suggest that trans-Pacific transport dust as the major aerosol component from north African desert, Middle Eastern and central Asian desert, and East Asian desert has similar contribution.

Similar to aerosol mass, aerosol number also decreases along the Pacific Ocean, with a peak in spring. Different from the mass composition of dust, the number concentration is dominated by sulfate. The aerosols with size $0.039-0.156 \mu \mathrm{m}$ (Bin1-Bin3) are the main number contributors during transport, but aerosol mass is dominated by the size range of $2.5-10.0 \mu \mathrm{m}$ below $2 \mathrm{~km}$, with a maximum at $5.0 \mu \mathrm{m}$ (about $40 \%$ ). Above $2 \mathrm{~km}$, the aerosol size of $1.25-5.0 \mu \mathrm{m}$ becomes the main mass distribution range with more than $40 \%$ contribution. These aerosol particles can reach the mid-to-upper troposphere during the intercontinental transport (Figs. 6 and 7) and could provide an important source of ice nuclei and influence the cloud radiative forcing.

While this study shows that about $80.8 \mathrm{Tg} \mathrm{year}^{-1}$ aerosols are exported from East Asia $\left(20\right.$ to $\left.50^{\circ} \mathrm{N}\right)$ with a peak (40.6 Tg) in spring, only about $26.7 \mathrm{Tg}$ year $^{-1}$ of aerosols arrive on the west coast of the US with a peak $\left(15.0 \mathrm{Tg}\right.$ year $\left.^{-1}\right)$ in spring. Over the regions west of North America, about $50 \%-60 \%$ of column aerosols are from trans-Pacific transport, except for the Nevada desert region, where dust aerosol from local deserts can contribute more than $60 \%$. Different from the transported aerosol contribution to the column and high-altitude atmosphere, surface aerosol is mainly from local areas, with more than $60 \%$ contribution in spring. Overall, dust contributes about $34.7 \%$ to the annual mean aerosol in the column, and sea salt is about $44.6 \%$ at the surface. 


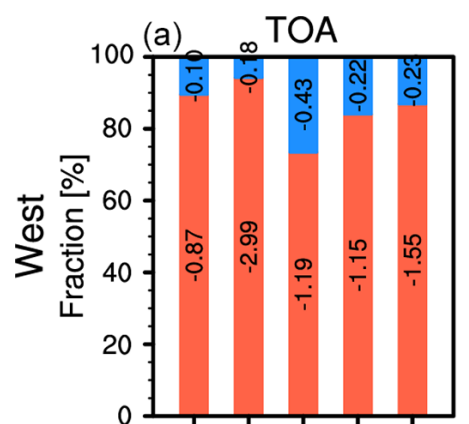

(d)

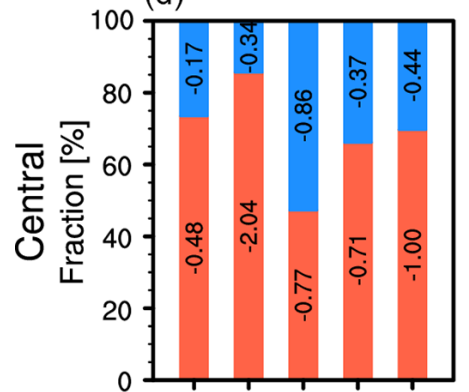

(g)

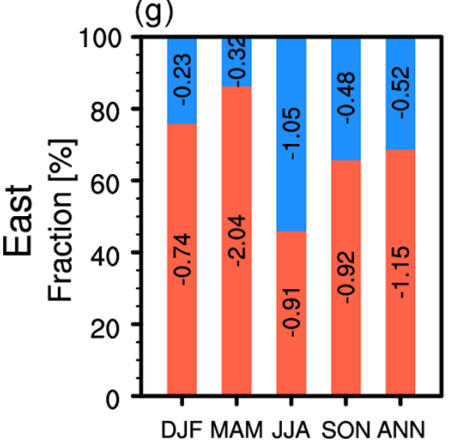

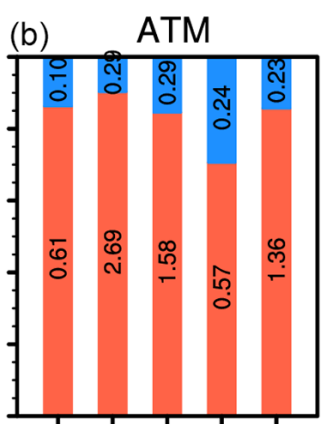

(e)

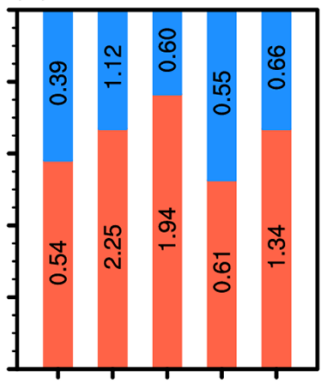

(h)

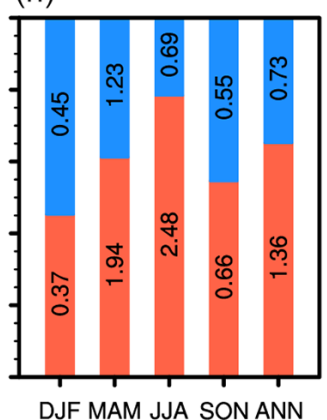

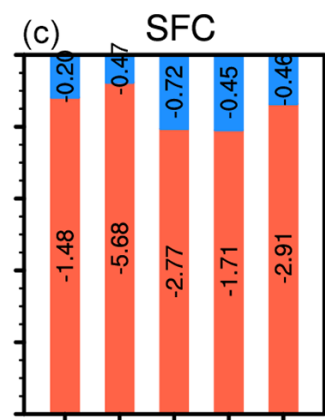

(f)

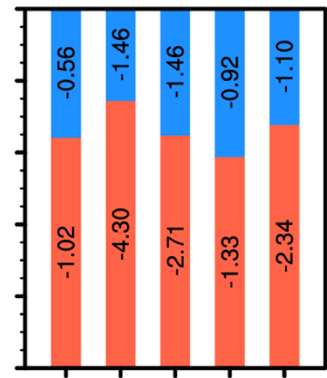

(i)

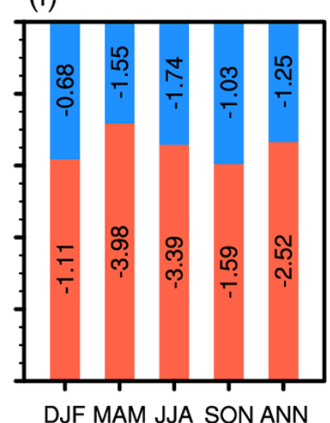

Figure 15. Seasonal and annual variation of radiative forcing fraction at the TOA (a, d, $\mathbf{g})$, in the atmosphere (b, e, h), and at the surface (c, f, i) from trans-Pacific transport (red) and US (blue) aerosols in western, central, and eastern North America for 2010-2014.

Over the central and eastern regions, the influence of local emission increases significantly, with OIN and nitrate aerosols contributing more than $30 \%$. Furthermore, dust from Africa is dominated by the transported aerosol through the Atlantic Ocean, especially in JJA, and consistent with Yu et al. (2015).

The impact of aerosols on regional climate can be characterized by the magnitude of radiative forcing. Our calculations show that aerosols can induce a warming and a cooling effect, respectively, in the atmosphere and at the surface. At the TOA, aerosols produce a cooling effect, except for $\mathrm{BC}$ aerosols with a warming effect. It is interesting to note that $\mathrm{BC}$, with smallest mass, can produce the largest direct radiative forcing, especially over polluted aerosol source regions (e.g., India, southeast China). Because of the strongest pollution aerosols and dust transport, the largest direct radiative forcing occurs in spring. For the North American region, the transported aerosols have an annual mean direct radiative forcing of -2.65 (at the SFC, $87.1 \%$ ), +1.41 (in the atmo- sphere, $87 \%$ ), and -1.52 (at TOA, $87.3 \%$ ) $\mathrm{W} \mathrm{m}^{-2}$ over the western North American region.

Based on the WRF-Chem simulations of aerosol transPacific transport, the aerosol characteristics and source contributions are analyzed. Modeling studies with reliable representations of aerosol transport mechanisms show that dust and pollution have significant impact on the surface air quality and radiative forcing in North America. However, the feedback on the trans-Pacific transport of dust and pollution from the changes in atmospheric circulations is not clear ( $\mathrm{Yu}$ et al., 2008). Long-term observations are needed to further evaluate the modeling results due to year-to-year variations of dust and increase of biomass burning emissions as the economic growth. Long-term modeling results may help study the interaction between transported aerosols and climate and better understand the impact of trans-Pacific aerosols on regional climate. 
Code availability. The release version (3.5.1) of WRF-Chem can be downloaded from http://www2.mmm.ucar.edu/wrf/users/ download/get_source.html (last access: 16 September 2019). The updated model is available upon contacting the first author (huzy@lzu.edu.cn). Also, the code modifications will be incorporated into the release version of WRF-Chem.

Supplement. The supplement related to this article is available online at: https://doi.org/10.5194/acp-19-12709-2019-supplement.

Author contributions. ZH and CZ conducted the quasi-global simulations. ZH performed the analyses, wrote the paper, and coordinated the paper. All authors contributed to the final version of the paper.

Competing interests. The authors declare that they have no conflict of interest.

Acknowledgements. We thank to the University of Science and Technology of China (USTC) for providing the updated version of Weather Research and Forecasting model with chemistry (WRFChem). We also thank to editor Michael Schulz and two anonymous referees for their insight and invaluable suggestions that improved this paper.

Financial support. This research was supported by the Foundation for National Natural Science Foundation of China (No. 41805116) and the Fundamental Research Funds for the Central Universities lzujbky-2018-49, lzujbky-2019-pd05, and lzujbky-2019-kb02, Innovative Research Groups of the National Science Foundation of China (grant no. 41521004) and Strategic Priority Research Program of Chinese Academy of Sciences, (Grant No. XDA20060103). Chun Zhao was supported by the National Natural Science Foundation of China NSFC (Grant No. 41775146) of China. Yun Qian and L. Ruby Leung were supported by Office of Science, US Department of Energy Biological and Environmental Research, through the Regional and Global Modeling and Analysis program. PNNL is operated by Battelle Memorial Institute for the US Department of Energy under contract DE-AC06-76RLO-1830.

Review statement. This paper was edited by Michael Schulz and reviewed by two anonymous referees.

\section{References}

Alizadeh-Choobari, O., Zawar-Reza, P., and Sturman, A.: The global distribution of mineral dust and its impacts on the climate system: A review, Atmos. Res., 138, 152-165, https://doi.org/10.1016/j.atmosres.2013.11.007, 2014.

Balkanski, Y., Schulz, M., Claquin, T., and Guibert, S.: Reevaluation of Mineral aerosol radiative forcings suggests a better agree- ment with satellite and AERONET data, Atmos. Chem. Phys., 7, 81-95, https://doi.org/10.5194/acp-7-81-2007, 2007.

Bi, J., Huang, J., Fu, Q., Ge, J., Shi, J., Zhou, T., and Zhang, W.: Field measurement of clear-sky solar irradiance in Badain Jaran Desert of northwestern China, J. Quant. Spectrosc. Ra., 122, 194-207, 2013.

Bi, J., Huang, J., Shi, J., Hu, Z., Zhou, T., Zhang, G., Huang, Z., Wang, X., and Jin, H.: Measurement of scattering and absorption properties of dust aerosol in a Gobi farmland region of northwestern China - a potential anthropogenic influence, Atmos. Chem. Phys., 17, 7775-7792, https://doi.org/10.5194/acp17-7775-2017, 2017.

Bian, H., Chin, M., Kawa, R., Duncan, B., Arellano Jr., A., and Kasibhatla, R.: Sensitivity of global CO simulations to uncertainties in biomass burning sources, J. Geophys. Res., 112, D23308, https://doi.org/10.1029/2006JD008376, 2007.

Binkowski, F. S. and Shankar, U.: The Regional Particulate Matter Model 1. Model description and preliminary results, J. Geophys. Res., 100, 26191-26209, 1995.

Bond, T. C., Doherty, S. J., Fahey, D. W., Forster, P. M., Berntsen, T., DeAngelo, B. J., Flanner, M. G., Chan, S., Kärcher, B., Koch, D., Kinne, D., Kondo, Y., Quinn, P. K.,Sarofim, M. C., Schultz, M. G., Schulz, M., Venkataraman, C., Zhang, H., Zhang, S., Bellouin, N., Guttikunda, S. K., Hopke, P. K., Jacobo, M. Z., Kaiser, J. W., Klimont, Z., Lohmann, U., Schwarz, J. P., Shindell, D., Storelvmo, T., Warren, S. G., and Zender C. S.: Bounding the role of black carbon in the climate system: A scientific assessment, J. Geophys. Res.-Atmos., 118, 5380-5552, https://doi.org/10.1002/jgrd.50171, 2013.

Bytnerowicz, A. and Fenn, M. E.: Nitrogen deposition in California forests: A review, Environ. Pollut., 92, 127-146, 1996.

Chapman, E. G., Gustafson Jr., W. I., easter, R. C., Barnard, J. C., Ghan, S. J., Pekour, M. S., and Fast, J. D.: Coupling aerosol-cloud-radiative processes in the WRF-Chem model: Investigating the radiative impact of elevated point sources, Atmos. Chem. Phys., 9, 945-964, https://doi.org/10.5194/acp-9945-2009, 2009.

Chin, M., Diehl, T., Ginoux, P., and Malm, W.: Intercontinental transport of pollution and dust aerosols: implications for regional air quality, Atmos. Chem. Phys., 7, 5501-5517, https://doi.org/10.5194/acp-7-5501-2007, 2007.

Creamean, J. M., Suski, K. J., Rosenfeld, D., Cazorla, A., DeMott, P. J., Sullivan, R. C., White, A. B., Ralph, F. M., Minnis, P., Comstock, J. M., Tomlinson, J. M., and Prather, K. A.: Dust and Biological Aerosols from the Sahara and Asia Influence Precipitation in the Western US, Science, 339, 1572, https://doi.org/10.1126/science.1227279, 2013.

Dickerson, R. R., Li, C., Li, Z., Marufu, L. T., Stehr, J. W., Chen, H., Wang, P., Xia, X., Ban, X., Gong, F., Yuan, J., and Yang, J.: Aircraft observations of dust and pollutants over NE China: Insight into the meteorological mechanisms of long-range transport, J. Geophys. Res., 112, D24S90, https://doi.org/10.1029/2007JD008999, 2007.

Dunion, J. and Velden, C.: The impact of the Saharan air layer on Atlantic tropical cyclone activity, B. Am. Meteorol. Soc., 85, 353-356, 2004.

Easter, R. C., Ghan, S. J., Zhang, Y., Saylor, R. D., Chapman, E. G., Laulainen, N. S., Abdul-Razzak, H., Leung, L. R., Bian, X., and Zaveri, R. A.: MIRAGE: Model Description and Evaluation 
of Aerosols and Trace Gases, J. Geophys. Res., 109, D20210, https://doi.org/10.1029/2004JD004571, 2004.

Eckhardt, S., Stohl, A., Wernli, H., James, P., Forster, C., and Spichtinger, N.: A 15-year climatology of warm conveyor belts, J. Climate, 17, 218-237, https://doi.org/10.1175/15200442(2004)017<0218:AYCOWC>2.0.CO;2, 2004.

Eguchi, K., Uno, I., Yumimoto, K., Takemura, T., Shimizu, A., Sugimoto, N., and Liu, Z.: Trans-pacific dust transport: integrated analysis of NASA/CALIPSO and a global aerosol transport model, Atmos. Chem. Phys., 9, 3137-3145, https://doi.org/10.5194/acp-9-3137-2009, 2009.

Fairlie, T. D., Jacob, D. J., and Park, R. J.: The impact of transpacific transport of mineral dust in the United States, Atmos. Environ., 41, 1251-1266, 2007.

Fairlie, T. D., Jacob, D. J., Dibb, J. E., Alexander, B., Avery, M. A., van Donkelaar, A., and Zhang, L.: Impact of mineral dust on nitrate, sulfate, and ozone in transpacific Asian pollution plumes, Atmos. Chem. Phys., 10, 3999-4012, https://doi.org/10.5194/acp-10-3999-2010, 2010.

Fan, J., Leung, L. R., DeMott, P. J., Comstock, J. M., Singh, B., Rosenfeld, D., Tomlinson, J. M., White, A., Prather, K. A., Minnis, P., Ayers, J. K., and Min, Q.: Aerosol impacts on California winter clouds and precipitation during CalWater 2011: local pollution versus long-range transported dust, Atmos. Chem. Phys., 14, 81-101, https://doi.org/10.5194/acp-14-81-2014, 2014.

Fan, J., Rosenfeld, D., Yang, Y., Zhao, C., Leung, L. R., and Li, Z.: Substantial contribution of anthropogenic air pollution to catastrophic floods in Southwest China, Geophys. Res. Lett., 42, 6066-6075, https://doi.org/10.1002/2015GL064479, 2015.

Fan, S.-M., Horowitz, L. W., Levy II, H., and Moxim, W. J.: Impact of air pollution on wet deposition of mineral dust aerosols, Geophys. Res. Lett., 31, L02104, https://doi.org/10.1029/2003GL018501, 2004.

Fast, J. D., Gustafson, W. I., Easter, R. C., Zaveri, R. A., Barnard, J. C., Chapman, E. G., Grell, G. A., and Peckham, S. E.: Evolution of ozone, particulates, and aerosol direct radiative forcing in the vicinity of Houston using a fully coupled meteorology chemistry-aerosol model, J. Geophys. Res., 111, D21305, https://doi.org/10.1029/2005JD006721, 2006.

Fast, J. D., Allan, J., Bahreini, R., Craven, J., Emmons, L., Ferrare, R., Hayes, P. L., Hodzic, A., Holloway, J., Hostetler, C., Jimenez, J. L., Jonsson, H., Liu, S., Liu, Y., Metcalf, A., Middlebrook, A., Nowak, J., Pekour, M., Perring, A., Russell, L., Sedlacek, A., Seinfeld, J., Setyan, A., Shilling, J., Shrivastava, M., Springston, S., Song, C., Subramanian, R., Taylor, J. W., Vinoj, V., Yang, Q., Zaveri, R. A., and Zhang, Q.: Modeling regional aerosol and aerosol precursor variability over California and its sensitivity to emissions and long-range transport during the 2010 CalNex and CARES campaigns, Atmos. Chem. Phys., 14, 10013-10060, https://doi.org/10.5194/acp-14-10013-2014, 2014.

Fischer, E. V., Hsu, N. C., Jaffe, D. A., Jeong, M.-J., and Gong, S. L.: A decade of dust: Asian dust and springtime aerosol load in theUSPacific Northwest, Geophys. Res. Lett., 36, L03821, https://doi.org/10.1029/2008GL036467, 2009.

Giglio, L., van der Werf, G. R., Randerson, J. T., Collatz, G. J., and Kasibhatla, P.: Global estimation of burned area using MODIS active fire observations, Atmos. Chem. Phys., 6, 957974, https://doi.org/10.5194/acp-6-957-2006, 2006.
Ginoux, P., Chin, M., Tegen, I., Prospero, J. M., Holben, B., Dubovik, O., and Lin, S. J.: Sources and distributions of dust aerosols simulated with the GOCART model, J. Geophys. Res., 106, 20255-20273, 2001.

Gong, S. L.: A parameterization of sea-salt aerosol source function for sub- and super-micron particles, Global Biogeochem. Cy., 17, 1097, https://doi.org/10.1029/2003GB002079, 2003.

Grell, G. A., Peckham, S. E., Schmitz, R., and McKeen, S. A., Frost, G., Skamarock, W. C., and Eder, B.: Fully coupled "online" chemistry within the WRF model, Atmos. Environ., 39, 6957-6976, 2005.

Hadley, O. L., Ramanathan, V., Carmichael, G. R., Tang, Y., Corrigan, C. E., Roberts, G. C., and Mauger, G. S.: TransPacific transport of black carbon and fine aerosols $(D<$ $2.5 \mathrm{~mm}$ ) into North America, J. Geophys. Res., 112, D05309, https://doi.org/10.1029/2006JD007632, 2007.

Heald, C. L., Jacob, D. J., Park, R. J., Alexander, B., Fairlie, T. D., Yantosca, R. M., and Chu, D. A.: Transpacific transport of Asian anthropogenic aerosols and its impact on surface air quality in the United States, J. Geophys. Res., 111, D14310, https://doi.org/10.1029/2005JD006847, 2006.

Holzer, M., McKendry, I. G., and Jaffe, D. A.: Springtime transPacific atmospheric transport from east Asia: A transittime probability density function approach, J. Geophys. Res., 108, 4708, https://doi.org/10.1029/2003JD003558, 2003.

Holzer, M., Hall, T. M., and Stull, R. B.: Seasonality and weather driven variability of transpacific transport, J. Geophys. Res.Atmos., 110, D23103, https://doi.org/10.1029/2005jd006261, 2005.

Hu, Z., Zhao, C., Huang, J., Leung, L. R., Qian, Y., Yu, H., Huang, L., and Kalashnikova, O. V.: Trans-Pacific transport and evolution of aerosols: evaluation of quasi-global WRF-Chem simulation with multiple observations, Geosci. Model Dev., 9, 17251746, https://doi.org/10.5194/gmd-9-1725-2016, 2016.

Hu, Z., Huang, J., Zhao, C., Bi, J., Jin, Q., Qian, Y., Leung, L. R., Feng, T., Chen, S., Ma, J.: Modeling the contributions of Northern Hemisphere dust sources to dust outflow from East Asia, Atmos. Environ., 202, 234-243, https://doi.org/10.1016/j.atmosenv.2019.01.022, 2019.

Huang, J., Lin, B., Minnis, P., Wang, T., Wang, X., Hu, Y., Yi, Y., and Ayers, J.: Satellite-based assessment of possible dust aerosols semi-direct effect on cloud water path over East Asia, Geophys. Res. Lett., 33, L19802, https://doi.org/10.1029/2006GL026561, 2006.

Huang, J., Minnis, P., Chen, B., Huang, Z., Liu, Z., Zhao, Q., Yi, Y., and Ayers, J.: Long-range transport and vertical structure of Asian dust from CALIPSO and surface measurements during PACDEX, J. Geophys. Res., 113, D23212, https://doi.org/10.1029/2008JD010620, 2008.

Huang, J., Fu, Q., Su, J., Tang, Q., Minnis, P., Hu, Y., Yi, Y., and Zhao, Q.: Taklimakan dust aerosol radiative heating derived from CALIPSO observations using the Fu-Liou radiation model with CERES constraints, Atmos. Chem. Phys., 9, 4011-4021, https://doi.org/10.5194/acp-9-4011-2009, 2009.

Huang, J., Fu, Q., Zhang, W., Wang, X., Zhang, R., Ye, H., and Warren, S.: Dust and black carbon in seasonal snow across northern China, B. Am. Meteorol. Soc., 92, 175-181, https://doi.org/10.1175/2010BAMS3064.1, 2011. 
Huang, J., Wang, T., Wang, W., Li, Z., and Yan, H.: Climate effects of dust aerosols over East Asian arid and semiarid regions, J. Geophys. Res.-Atmos., 119, 11398-11416, https://doi.org/10.1002/2014JD021796, 2014.

Huebert, B. J., Bates, T., Russell, P. B., Shi, G., Kim, Y. J., Kawamura, K., Carmichael, G., and Nakajima, T.: An overview of ACE-Asia: strategies for quantifying the relationships between Asian aerosols and their climatic impacts, J. Geophys. Res. 108, 8633, https://doi.org/10.1029/2003JD003550, 2003.

Jacob, D. J., Crawford, J. H., Kleb, M. M., Connors, V. S., Bendura, R. J., Raper, J. R. , Sachse, G. W., Gille, J. C., Emmons, L., and Heald, C. L.: Transport and Chemical Evolution over the Pacific (TRACE-P) aircraft mission: Design, execution, and first results, J. Geophys. Res., 108, 9000, https://doi.org/10.1029/2002JD003276, 2003.

Jaffe, D., Anderson, T., Covert, D., Kotchenruther, R., Trost, B., Danielson, J., Simpson, W., Berntsen, T., Karlsdottir, S., Blake, D., Harris, J., Carmichael, G., and Uno, I.: Transport of Asian Air Pollution to North America, Geophys. Res. Lett., 26, 711714, 1999.

Jaeglé, L., Quinn, P. K., Bates, T. S., Alexander, B., and Lin, J.-T.: Global distribution of sea salt aerosols: new constraints from in situ and remote sensing observations, Atmos. Chem. Phys., 11, 3137-3157, https://doi.org/10.5194/acp-11-3137-2011, 2011.

Janssens-Maenhout, G., Crippa, M., Guizzardi, D., Dentener, F., Muntean, M., Pouliot, G., Keating, T., Zhang, Q., Kurokawa, J., Wankmüller, R., Denier van der Gon, H., Kuenen, J. J. P., Klimont, Z., Frost, G., Darras, S., Koffi, B., and Li, M.: HTAP_v2.2: a mosaic of regional and global emission grid maps for 2008 and 2010 to study hemispheric transport of air pollution, Atmos. Chem. Phys., 15, 11411-11432, https://doi.org/10.5194/acp-15-11411-2015, 2015.

Jimenez, J. L., Canagaratna, M. R., Donahue, N. M., Prevot, A. S. H., Zhang, Q., Kroll, J. H., DeCarlo, P. F., Allan, J. D., Coe, H., Ng, N. L., Aiken, A. C., Docherty, K. S., Ulbrich, I. M., Grieshop, A. P., Robinson, A. L., Duplissy, J., Smith, J. D., Wilson, K. R., Lanz, V. A., Hueglin, C., Sun, Y. L., Tian, J., Laaksonen, A., Raatikainen, T., Rautiainen, J., Vaattovaara, P., Ehn, M., Kulmala, M., Tomlinson, J. M., Collins, D. R., Cubison, M. J., Dunlea, E. J., Huffman, J. A., Onasch, T. B., Alfarra, M. R., Williams, P. I., Bower, K., Kondo, Y., Schneider, J., Drewnick, F., Borrmann, S., Weimer, S., Demerjian, K., Salcedo, D., Cottrell, L., Griffin, R., Takami, A., Miyoshi, T., Hatakeyama, S., Shimono, A., Sun, J. Y, Zhang, Y. M., Dzepina, K., Kimmel, J. R., Sueper, D., Middlebrook, A. M., Kolb, C. E., Baltensperger, U., and Worsnop, D. R.: Evolution of Organic Aerosols in the Atmosphere, Science, 326, 1525, https://doi.org/10.1126/science.1180353, 2009.

Jones, A., Haywood, J. M., and Boucher, O.: Aerosol forcing, climate response and climate sensitivity in the Hadley Centre climate model, J. Geophys. Res., 112, 211, https://doi.org/10.1029/2007JD008688, 2007.

Kelly, J. T., Chuang, C. C., and Wexler, A. S.: Influence of dust composition on cloud droplet formation, Atmos. Environ., 41, 2904-2916, 2007.

Kim, K. W., Zhuanshi, H., and Kim, Y. J.: Physicochemical characteristics and radiative properties of Asian dust, J. Geophys. Res., 109, D19S02, https://doi.org/10.1029/2003JD003693, 2004.
Klingmüller, K., Lelieveld, J., Karydis, V. A., and Stenchikov, G. L.: Direct radiative effect of dust-pollution interactions, Atmos. Chem. Phys., 19, 7397-7408, https://doi.org/10.5194/acp19-7397-2019, 2019.

Koehler, K. A., Kreidenweis, S. M., DeMott, P. J., Prenni, A. J., and Petters, M. D.: Potential impact of Owens (dry) Lake dust on warm and cold cloud formation, J. Geophys. Res., 112, 11031118, 2007.

Kulmala, M., Asmi, A., Lappalainen, H. K., Carslaw, K. S., Pöschl, U., Baltensperger, U., Hov, Ø., Brenquier, J.-L., Pandis, S. N., Facchini, M. C., Hansson, H.-C., Wiedensohler, A., and O'Dowd, C. D.: Introduction: European Integrated Project on Aerosol Cloud Climate and Air Quality interactions (EUCAARI) - integrating aerosol research from nano to global scales, Atmos. Chem. Phys., 9, 2825-2841, https://doi.org/10.5194/acp-9-28252009, 2009.

Lau, K., Ramanathan, V.,Wu, G., Li, Z., Tsay, S., Hsu, C., Sikka, R.,Holben, B., Lu, D., Tartari, G., Chin, M., Koudelova, P., Chen,H., Ma, Y., Huang, J., Taniguchi, K., and Zhang, R.: The joint aerosol-monsoon experiment: A new challenge for monsoon climate research, B. Am. Meteorol. Soc., 89, 369-383, 2008.

Lee, Y. C., Yang, X., and Wenig, M.: Transport of dusts from East Asian and non-East Asian sources to Hong Kong during dust storm related events 1996-2007, Atmos. Environ., 44, 37283738, 2010.

Li, J., Jian, B., Huang, J., Hu, Y., Zhao, C., Kawamoto, K., Liao, S., and $\mathrm{Wu}, \mathrm{M}$.: Long-term variation of cloud droplet number concentrations from space-based Lidar, Remote Sens. Environ., 213, 144-161, doi.org/10.1016/j.rse.2018.05.011, 2018.

Liang, Q., Jaegle, L., Jaffe, D. A., Weiss-Penzias, P., Heckman, A., and Snow, J. A.: Long-range transport of Asian pollution to the northeast Pacific: Seasonal variations and transport pathways of carbon monoxide, J. Geophys. Res., 109, D23S07, https://doi.org/10.1029/2003JD004402, 2004.

Liao, H. and Seinfeld, J. H.: Global impacts of gas-phase chemistryaerosol interactions on direct radiative forcing by anthropogenic aerosols and ozone, J. Geophys. Res., 110, D18208, https://doi.org/10.1029/2005JD005907, 2005.

Mahowald, N., Jickells, T. D., Baker, A. R., Artaxo, P., BenitezNelson, C. R., Bergametti, G., Bond, T. C., Chen, Y., Cohen, D. D., Herut, B., Kubilay, N., Losno, R., Luo, C., Maenhaut, W., McGee, K. A., Okin, G. S., Siefert, R. L., and Tsukuda, S.: The global distribution of atmospheric phosphorus deposition and anthropogenic impacts, Global Biogeochem. Cy., 22, GB4026, https://doi.org/10.1029/2008GB003240, 2008.

Painter, T. H., Deems, J. S., Belnap, J., Hamlet, A. F., Landry, C. C., and Udall, B.: Response of Colorado River runoff to dust radiative forcing in snow, P. Natl. Acad. Sci. USA, 107, 1712517130, https://doi.org/10.1073/pnas.0913139107, 2010.

Park, C. B., Sugimoto, N., Matsui, I., Shimizu, A., Tatarov, B., Kamei, A., Lee, C. H., Uno, I., Takemura, T., and Westphal, D. L.: Long-range Transport of Saharan Dust to East Asia Observed with Lidars, Scientific Online Letters on the Atmosphere Sola, 1, 121e124, doi:10.2151/sola.2005-032, 2005.

Parrish, D. D., Kondo, Y., Cooper, O. R., Brock, C. A., Jaffe, D. A., Trainer, M., Ogawa, T., Hübler, G., and Fehsenfeld, F. C.: Intercontinental Transport and Chemical Transformation 2002 (ITCT 2K2) and Pacific Exploration of Asian Continen- 
tal Emission (PEACE) experiments: An overview of the 2002 winter and spring intensives, J. Geophys. Res., 109, D23S01, https://doi.org/10.1029/2004JD004980, 2004.

Pope, C. A. I.: Review: Epidemiological Basis for Particulate Air Pollution Health Standards, Aerosol Sci. Tech., 32, 4-14, 2000.

Pope, C. A. III, Burnett, R. T., Thun, M. J., Calle, E. E., Krewski, D., Ito, K., and Thurston, G. D.: Lung Cancer, Cardiopulmonary Mortality, and Long-term Exposure to Fine Particulate Air Pollution, J. Am. Med. Assoc., 287, 1132-1141, 2002.

Qian, Y., Gustafson, W. I., Leung, L. R., and Ghan, S. J.: Effects of soot-induced snow albedo change on snowpack and hydrological cycle in western United States basedon Weather Research and Forecasting chemistryand regional climate simulations, J. Geophys. Res., 114, D03108, https://doi.org/10.1029/2008JD011039, 2009.

Qian, Y., Yan, H., Hou, Z., Johannesson, C., Klein, S., Lucas, D., Neale, R., Rasch, P., Swiler, L., Tannahill, J., Wang, H., Wang, M., and Zhao, C.: Parametric sensitivity analysis of precipitation at global and local scales in the Community Atmosphere Model CAM5, J. Adv. Model. Earth Syst., 7, 382-411, https://doi.org/10.1002/2014MS000354, 2015.

Jin, Q., Wei, J., and Yang, Z.-L.: Positive response of Indian summer rainfall to Middle East dust, Geophys. Res. Lett., 41, 4068-4074, https://doi.org/10.1002/2014GL059980, 2014.

Jin, Q., Wei, J., Yang, Z.-L., Pu, B., and Huang, J.: Consistent response of Indian summer monsoon to Middle East dust in observations and simulations, Atmos. Chem. Phys., 15, 9897-9915, https://doi.org/10.5194/acp-15-9897-2015, 2015.

Jin, Q., Yang, Z.-L., and Wei, J.: Seasonal Responses of Indian Summer Monsoon to Dust Aerosols in the Middle East, India, and China, J. Climate, 29, 632-6349, https://doi.org/10.1175/jcli-d-15-0622.1, 2016.

Jin, Q., Grandey, B. S., Rothenberg, D., Avramov, A., and Wang, C.: Impacts on cloud radiative effects induced by coexisting aerosols converted from international shipping and maritime DMS emissions, Atmos. Chem. Phys., 18, 16793-16808, https://doi.org/10.5194/acp-18-16793-2018, 2018.

Rosenfeld, D., Rudich, Y., and Lahav, R.: Desert dust suppressing precipitation: a possible desertification feedback loop, P. Natl. Acad. Sci. USA, 98, 5975-5980, 2001.

Schindler, D. W.: Effects of Acid-Rain on Fresh-Water Ecosystems, Science, 239, 149-157, 1988.

Schindler, D.: From acid rain to toxic snow, Ambio, 28, 350-355, 1999.

Schwartz, J.: Air-Pollution and Daily Mortality - a Review and Meta Analysis, Environ. Res., 64, 36-52, 1994.

Singh, H. B., Brune, W. H., Crawford, J. H., Flocke, F., and Jacob, D. J.: Chemistry and transport of pollution over the Gulf of Mexico and the Pacific: spring 2006 INTEX-B campaign overview and first results, Atmos. Chem. Phys., 9, 2301-2318, https://doi.org/10.5194/acp-9-2301-2009, 2009.

Solomon, S.: Stratospheric Ozone Depletion: A Review of Concepts and History, Rev. Geophys., 37, 275-316, 1999.

Takemura T., Nakajima, T., Dubovik, O., Holben, B. N., and Kinne, S.: Single-scattering albedo and radiative forcing of various aerosol species with a global three-dimensional model, J. Climate, 15, 333-352, 2002.
Tao, Z., Yu, H., and Chin, M.: Impact of transpacific aerosol on air quality over the United States: A perspective from aerosolcloudradiation interactions, Atmos. Environ., 125, 48-60, 2016.

Uno, I., Eguchi, K., Yumimoto, K., Takemura, T., Shimizu, A., Uematsu, M., Liu, Z., Wang, Z., Hara, Y., and Sugimoto, N.: Asian dust transported one full circuit around the globe, Nat. Geosci., 2, 557-560, https://doi.org/10.1038/ngeo583, 2009.

Uno, I., Eguchi, K., Yumimoto, K., Liu, Z., Hara, Y., Sugimoto, N., Shimizu, A., and Takemura, T.: Large Asian dust layers continuously reached North America in April 2010, Atmos. Chem. Phys., 11, 7333-7341, https://doi.org/10.5194/acp-117333-2011, 2011.

VanCuren, R. A.: Asian aerosols in North America: Extracting the chemical composition and mass concentration of the Asian continental aerosol plume from long-term aerosol records in the western United States, J. Geophys. Res., 108, 4623, https://doi.org/10.1029/2003JD003459, 2003.

Wang, H., Rasch, P. J., Easter, R. C., Singh, B., Zhang, R., Ma, P. L., Qian, Y., and Beagley, N.: Using an explicit emission tagging method in global modeling of source-receptor relationships for black carbon in the Arctic: Variations, Sources and Transport pathways, J. Geophys. Res.-Atmos., 119, 12888-12909, https://doi.org/10.1002/2014JD022297, 2014.

Watson, J. G.: Visibility: Science and regulation, J. Air Waste Manage., 52, 628-713, 2002.

Wiedinmyer, C., Akagi, S. K., Yokelson, R. J., Emmons, L. K., AlSaadi, J. A., Orlando, J. J., and Soja, A. J.: The Fire INventory from NCAR (FINN): a high resolution global model to estimate the emissions from open burning, Geosci. Model Dev., 4, 625641, https://doi.org/10.5194/gmd-4-625-2011, 2011.

Wilcox, E. M., Lau, K. M., and Kim, K. M.: A northward shift of the North Atlantic Ocean Intertropical Convergence Zone in response to summertime saharan dust outbreaks, Geophys. Res. Lett., 37, 90-98, 2010.

Wuebbles, D. J., Lei, H., and Lin, J.: Intercontinental transport of aerosols and photochemical oxidants from Asia and its consequences, Environ. Pollut., 150, 65-84, 2007.

Yienger, J. J., Galanter, M., Holloway, T. A., Phadnis, M. J., Guttikunda,S. K., Carmichael, G. R., and Moxim II, W. J.: The episodicnature of air pollution transport from Asia to North America, J.Geophys. Res., 105, 26931-26945, 2000.

Yu, H. B., Remer, L. A., Chin, M., Bian, H. S., Kleidman, R. G., and Diehl, T.: A satellite-based assessment of transpacific transport of pollution aerosol, J. Geophys. Res., 113, D14S12, https://doi.org/10.1029/2007JD009349, 2008.

Yu, H., Remer, L. A., Chin, M., Bian, H., Tan, Q., Yuan, T., and Zhang, Y.: Aerosols from Overseas Rival Domestic Emissions over North America, Science, 337, 566-569, 2012.

Yu, H., Remer, L. A., Kahn, R. A., Chin, M., and Zhang Y.: Satellite perspective of aerosol intercontinental transport: From qualitative tracking to quantitative characterization, Atmos. Res., 124, 73-100, https://doi.org/10.1016/j.atmosres.2012.12.013, 2013.

Yu, H., Chin, M., Bian, H., Yuan, T. L., Prospero, J. M., Omar, A. H., Remer, L. A., Winker, D. M., Yang, Y., Zhang, Y., and Zhang, Z.: Quantification of trans-Atlantic dust transport from seven-year (2007-2013) record of CALIPSO lidar measurements, Remote Sens. Environ., 159, 232-249, https://doi.org/10.1016/j.rse.2014.12.010, 2015. 
Zaveri, R. A. and Peters, L. K.: A new lumped structure photochemical mechanism for large-scale applications, J. Geophys. Res., 104, 30387-30415, 1999.

Zaveri, R. A., Easter, R. C., Fast, J. D., and Peters, L. K.: Model for Simulating Aerosol Interactions and Chemistry (MOSAIC), J. Geophys. Res., 113, D13204, https://doi.org/10.1029/2007JD008782, 2008.

Zhao, C., Liu, X., Leung, L. R., Johnson, B., McFarlane, S. A., Gustafson Jr., W. I., Fast, J. D., and Easter, R.: The spatial distribution of mineral dust and its shortwave radiative forcing over North Africa: modeling sensitivities to dust emissions and aerosol size treatments, Atmos. Chem. Phys., 10, 8821-8838, https://doi.org/10.5194/acp-10-8821-2010, 2010.

Zhao, C., Liu, X., Ruby Leung, L., and Hagos, S.: Radiative impact of mineral dust on monsoon precipitation variability over West Africa, Atmos. Chem. Phys., 11, 1879-1893, https://doi.org/10.5194/acp-11-1879-2011, 2011.
Zhao, C., Liu, X., and Leung, L. R.: Impact of the Desert dust on the summer monsoon system over Southwestern North America, Atmos. Chem. Phys., 12, 3717-3731, https://doi.org/10.5194/acp12-3717-2012, 2012.

Zhao, C., Leung, L. R., Easter, R., Hand, J., and Avise, J.: Characterization of speciated aerosol direct radiative forcing over California, J. Geophys. Res., 118, 2372-2388, https://doi.org/10.1029/2012JD018364, 2013a.

Zhao, C., Chen, S., Leung, L. R., Qian, Y., Kok, J. F., Zaveri, R. A., and Huang, J.: Uncertainty in modeling dust mass balance and radiative forcing from size parameterization, Atmos. Chem. Phys., 13, 10733-10753, https://doi.org/10.5194/acp-13-107332013, 2013 b.

Zhao, C., Hu, Z., Qian, Y., Ruby Leung, L., Huang, J., Huang, M., Jin, J., Flanner, M. G., Zhang, R., Wang, H., Yan, H., Lu, Z., and Streets, D. G.: Simulating black carbon and dust and their radiative forcing in seasonal snow: a case study over North China with field campaign measurements, Atmos. Chem. Phys., 14, 1147511491, https://doi.org/10.5194/acp-14-11475-2014, 2014. 